\title{
PERANAN BADAN PEMIKIR DALAM WACANA TURKI - KESATUAN EROPAH: KAJIAN KES İKTISADI KALKINMA VAKFI (İKV)
}

\author{
Mohd Safwan Saparudin ${ }^{1, *}$, Russli Kamarudin ${ }^{1}$ \\ ${ }^{1}$ Pusat Penyelidikan Sejarah, Politik dan Hubungan Antarabangsa, Fakulti Sains Sosial dan Kemanusiaan, \\ Universiti Kebangsaan Malaysia, 43600 Bangi, Selangor, MALAYSIA.
}

\begin{abstract}
The role of Non-Governmental Organization (NGO) is increasingly prominent in foreign policy development. In the context of Turkey's integration into the European Union (EU), independent think tanks are seen as the "prime mover" in efforts to generating ideas and strategies, driving engagement projects, and developing integration discourses among stakeholders such as the political elites, community of entrepreneurs, scholars, as well as local and foreign interest groups. The main objective of this article is to assess the efficiency of various approaches spearheaded by a Turkish think tank group in achieving Turkey's strategic goal of joining the EU. It also seeks to examine the role of a think tank group, based on the taxonomic framework of public diplomacy. As a case study, the role of the Economic Development Foundation - İktisadi Kalkinma Vakfi (IKV) was examined qualitatively, through interview and analysis documents sourced from research reports, papers, and websites. This study finds that the influence of independent think tanks is increasingly needed in the process of agenda framing, formulation, implementation, and monitoring of Ankara-Brussels relations strategic policies. In the realm of public diplomacy, the dialogue and engagement initiatives driven by NSA have the potential to stimulate cooperation and mutual understanding in managing polemics and socio-political gaps.
\end{abstract}

Keywords: Turkey; European Union; Foreign Policy; Public Diplomacy; Think Tank

*Corresponding author: safwanlaw@gmail.com eISSN: 2636-9257 CPusat Dialog Peradaban Universiti Malaya, 2021

DOI: https://doi.org/10.22452/PERADABAN.vol14no1.4 


\begin{abstract}
Abstrak
Peranan Badan Bukan Kerajaan (BBK) semakin menyinar dalam wacana pembangunan dasar-dasar luar negeri dan hubungan antarabangsa. Dalam konteks perjalanan integrasi Turki ke dalam Kesatuan Eropah (EU), badan pemikir yang bebas dilihat berfungsi sebagai "enjin utama" dalam usaha-usaha menjana idea dan strategi, memacu projek-projek libaturus serta mengembangkan wacana integrasi dalam kalangan pemegang-pemegang taruh seperti elit politik, komuniti usahawan, cendekiawan, kumpulan berkepentingan termasuk rakyat awam asing. Objektif utama kajian ini adalah untuk menilai keberkesanan pelbagai pendekatan yang diterajui oleh badan pemikir Turki dalam menjayakan matlamat strategik Turki menganggotai EU. Makalah ini juga berusaha meninjau peranan badan pemikir yang terlibat secara langsung, berdasarkan kerangka taksonomi diplomasi awam. Sebagai kajian kes, peranan Yayasan Pembangunan Ekonomi - İktisadi Kalkınma Vakfı (IKV) diteliti secara kualitatif, menerusi kaedah temu bual dan dokumen analisis bersumberkan laporan penyelidikan dan makalah. Kajian ini mendapati pengaruh badan pemikir yang bebas semakin diperlukan dalam proses pembingkaian agenda, memformulasi pelaksanaan dan pemantauan dasar-dasar strategik hubungan Ankara-Brussels. Dalam arena diplomasi awam, inisiatif dialog dan libaturus yang dipacu oleh BBK berpotensi merangsang hubungan kerjasama dan kesefahaman bersama dalam mengurus polemik dan jurang sosio-politik yang semakin mendalam.
\end{abstract}

Kata Kunci: Turki; Kesatuan Eropah; Dasar Luar; Diplomasi Awam; Badan Pemikir

\title{
Pengenalan
}

Peranan Badan Bukan Kerajaan (BBK) tidak dapat diabaikan dalam wacana pembangunan dasar-dasar domestik mahupun luar negeri. Impak langsung daripada pendemokrasian, globalisasi dan evolusi teknologi moden telah merangsang pengaruh BBK seiring dengan peranan aparatus kerajaan serta blok-blok politik dan ekonomi yang berpengaruh. Dalam banyak situasi, sentuhan BBK didapati lebih berkesan berbanding peranan aktor kerajaan atau agensi-agensinya. Beberapa peristiwa yang menggemparkan dunia seperti Arab Spring, \#Occupywallstreet dan Freedom Flotilla ke Gaza sebagai contoh telah dicetuskan BBK dan secara langsung merubah lanskap politik, ekonomi dan sosial masyarakat.

Dalam arena diplomasi awam, BBK memiliki peranannya yang tersendiri dalam mencorak dasar luar serta menyebarkan pengaruhnya kepada sasaran pemegang taruh mereka bagi mencapai matlamat dasar luar sesebuah negara. Sebagai salah satu instrumen Soft Power, diplomasi awam dimanfaatkan oleh kebanyakan kerajaan dan BBK bagi mencapai objektif-objektif advokasi, pengaruh, pembingkaian agenda dan mobilisasi; mengukuhkan dasar-dasar luar; promosi dan prestij; membetulkan salahtanggapan; ruang dialog dan saling memahami; dan keharmonian berdasarkan nilai-nilai universal (Kalın, 2011). Berbanding aparatus kerajaan, BBK memiliki kekuatan tersendiri untuk menembusi pasaran serta relung yang sukar dicapai oleh 
kerajaan; keupayaan sebagai broker serta gatekeeper dalam menyelia proses pertukaran maklumat; bebas daripada birokrasi; dan lebih fleksibel dalam menentukan arah tuju, had masa dan inisiatif-inisiatif yang dirangka (Mellisen, 2005).

Berdasarkan konsep Soft Power, kejayaan sesuatu matlamat dasar luar boleh dicapai menerusi seni-seni diplomasi yang dijana untuk mempengaruhi pihak lain secara kreatif, strategik dan berkesan (Nye, 2011). Pengaruh Soft Power dapat diukur dengan keberkesanan enjin diplomatik melalui forum politik dan ekonomi peringkat tertinggi, peranan badan pemikir, gerakan melobi serta strategi komunikasi. Tidak dapat dinafikan secara konsensus, diplomasi dalam konteks Ankara-Brussels adalah jalan utama untuk membina jambatan dan hubungan kerjasama yang berkesan antara Turki dan EU (Nas, 2021).

Dalam konteks wacana Ankara-Brussels, khususnya pasca 2013, wacana AnkaraBrussels mengalami era kebuntuan (deadlock), satu keadaan yang menyulitkan proses penyertaan Turki dalam Kesatuan Eropah akibat dihimpit bermacam krisis dan polemik. Salah satu aspek utama dalam menangani kebuntuan tersebut adalah komunikasi dan penjernihan persepsi negatif dalam kalangan komuniti Eropah (Hatipoğlu, Muftuler-Bac \& Karakoc, 2013). Oleh yang demikian, kajian ini berusaha menjawab persoalan: berkesankah pendekatan-pendekatan badan pemikir untuk memperbaiki komunikasi dan mencairkan prejudis komuniti Eropah terhadap Turki? Maka, objektif utama kajian ini akan berusaha menilai keberkesanan pelbagai pendekatan badan pemikir Turki khususnya, dalam menjayakan matlamat strategik Turki menganggotai Kesatuan Eropah (EU).

Kajian ini bersifat kualitatif menggunakan kaedah temu bual dan analisis dokumen bersumberkan laporan penyelidikan dan makalah. Tumpuan kajian kes akan meninjau peranan sebuah badan pemikir Turki, iaitu Yayasan Pembangunan Ekonomi atau İktisadi Kalkınma Vakfi (IKKV) bagi memahami gambaran besar (big picture) peranan yang dimainkan, proses yang dialami serta impak yang dijana oleh badan pemikir tersebut dalam kerangka menjayakan matlamat strategik dasar luar Turki. Pendekatan kajian kes dipilih kerana ia bukan sekadar bersifat deskriptif tapi juga eksploratif bagi meninjau keberkesanan badan pemikir dalam menjayakan proses pembingkaian agenda, formulasi, pelaksanaan dan pemantauan dasar-dasar luar. Penyelidik mendapati badan pemikir yang bebas (independent) dilihat telah berfungsi sebagai "enjin utama" dalam usaha menjana idea dan strategi, menggerakkan dan memandu projek serta menghubungkan wacana dalam kalangan rakyat Turki, negara-negara EU serta institusi-institusi EU itu sendiri. Tidak mustahil, "enjin diplomasi" yang sedang bergerak tersebut mampu menangani halangan-halangan integrasi dan mengubah status quo wacana Ankara-Brussels tersebut.

Pelbagai strategi dan usaha telah dijalankan bagi memperbaiki hubungan bilateral Ankara-Brussels melalui penglibatan aparatus kerajaan Turki termasuklah Badan Bukan Kerajaan (BBK). Namun, ia belum menampakkan sinar (Servantie, 2017). 
Dalam kajian ini, penyelidik mendapati faktor-faktor yang menghalang integrasi Ankara-Brussels berpotensi ditangani secara berkesan melalui meja rundingan, dialog dan libaturus yang meletakkan tumpuan utama kerjasama dan persefahaman sebagai dasar hubungan strategik.

\section{Integrasi Ankara-Brussels Di Era Kemerosotan}

Proses integrasi Turki dalam Eropah telah melalui beberapa fasa sejarah hubungan diplomatik. Interaksi terawal boleh ditemui pada tahun 1963 apabila Perjanjian Ankara termeterai, yang mencatatkan batu tanda (milestone) yang penting dalam projek integrasi Turki dalam Eropah. Lecha (2019) mendapati di era keemasan hubungan Ankara-Brussels antara tahun 1999 dan 2006, Turki telah diterima sebagai calon anggota EU (1999) dan rundingan keanggotaan dibuka (2005). Dalam era mendatar antara tahun 2007 dan 2012, beberapa insiden berlaku yang merumitkan hubungan seperti Perancis dan Cyprus menghalang pembukaan beberapa fasal rundingan (2007), kemunculan kes Ergenekon dan Sledgehammer di Turki (2008), Arab Spring tercetus (2010) dan EU melancarkan Agenda Positif (2012). Antara tahun 2013 dan 2020, hubungan Ankara-Brussels mengalami era kemerosotan yang mendorong berlakunya kebuntuan dan kebingungan. Dalam fasa tersebut, beberapa polemik telah tercetus. Antaranya peristiwa protes Gezi (2013), AKP menang majoriti (2015), perjanjian pelarian Turki-EU (2016), cubaan kudeta yang gagala (2016), referendum perlembagaan Turki (2017), Erdoğan dilantik sebagai Presiden (2018) dan pembekuan rundingan keanggotaan (2019) (Safwan \& Russli, 2019).

Tocci (2016) merumuskan analisis senario halangan - halangan yang wujud dalam proses penyertaan Turki dalam EU dalam era kemerosotan tersebut berdasarkan enam dimensi: politik; ekonomi; tenaga; keselamatan; migrasi dan mobiliti; dan identitibudaya. Pertama, fasa ini dimulai dengan kocakan politik dalaman Turki khususnya peristiwa protes rakyat di Taman Gezi, pasca cubaan kudeta dan kesan sistem presidensi. Klimaksnya, pada tahun 2019 EU memutuskan menghentikan rundingan keanggotaan berdasarkan kemerosotan dalam dimensi politik berikutan tuduhantuduhan EU berkisar kecenderungan sistem presidensi kepada otoritarianisme, dominasi wacana umum berhubung langkah Brexit, Euroskeptisisme, migrasi dan isu hukuman mati mandatori. Dalam dimensi ekonomi pula, kerjasama ekonomi semakin menyusut daripada Kesatuan Kastam kepada FTA, kemuncupan pelaburan dana asing EU ke Turki dan perangkap pendapatan kumpulan pertengahan (middle-income trap) (Tocci, 2016).

Turki seumpama "serigala yang keseorangan" dalam berinteraksi dengan sekutunya dari Eropah dan bukan Eropah seperti Timur Tengah, Eurasia dan negara-negara BRICS (Elmener, 2017). Dasar keselamatan menunjukkan penjarakan antara Turki dan dunia barat. Campurtangan Turki dalam kancah pertelingkahan di Timur Tengah dan Eurasia menimbulkan persepsi yang Turki lebih berat sebelah kepada kelompok Sunni dan aktor bukan kerajaan (Donelli, 2020). "Persahabatan" dengan Iran dan Rusia dalam menangani konflik Syria juga mengundang perasaan "kurang senang" oleh Amerika 
Syarikat, NATO dan EU yang hanya lebih cenderung kepada sesi-sesi dialog berbanding tindakan bersifat pragmatik dan konkrit (Elmener, 2017).

Sektor tenaga memerlukan Turki sebagai rakan kongsi penting kepada EU. Namun, Ankara tidak menganggotai komuniti tenaga EU. Turki bergantung kepada sumber gas dari Moscow, dikenali sebagai projek "Turkish Stream" yang rancak diteruskan selepas perang saraf Turki-Rusia akibat kes tentera Turki menembak jatuh pesawat Rusia di Syria tahun 2016 (Ostakhova \& Sezer, 2020). Cyprus pula mengelakkan diri daripada Turki untuk menyalurkan gas dari Mediteranean Timur ke Eropah sebaliknya melalui Mesir. Pertikaian hak maritim di perairan Mediterranean timur dan lautan Aegean sejak 1970-an kembali menghangatkan hubungan Ankara-Athens (Kantouris, Bilginsoy \& Gatopoulos, 2020). Usaha rundingan dilihat masih gagal dan hubungan Ankara-Athen kekal dingin bagi menyelesaikan hak pemilikan sumber asli seperti deposit gas yang penting kepada ekonomi serantau.

Dalam dimensi migrasi dan mobiliti, Turki mengalami fenomena luar biasa kerana terperangkap dalam "koridor migrasi" akibat kadar penghijrahan yang amat tinggi terutamanya dari negara-negara berkonflik di Timur Tengah seperti Syria, Mesir dan Iraq serta Afrika dan Eurasia yang menuju ke Turki dan negara-negara Eropah (World Migration Report, 2020). Kesannya, Turki menjadi hab penghijrah asing terbesar di dunia pasca perang saudara di Syria meletus dengan populasi melebihi empat juta pelarian yang terpaksa menumpang teduh di Turki. Selain itu, ekoran pendekatan kerajaan yang disinonimkan dengan otorianisme, pasca peristiwa cubaan kudeta memaksa kumpulan Gulenis serta simpatisan Gulen dan pertentangan keras antara kerajaan dan fraksi keganasan Kurdistan seperti PKK, ribuan rakyat Turki telah berhijrah ke Eropah. Hubungan Ankara dan Brussels semakin renggang berikutan termeterainya perjanjian penyelesaian penghijrah pada tahun 2016, yang memutuskan tiga perkara utama; iaitu Kesatuan Eropah hendaklah menyuntik dana sebanyak €3 Billion (RM15 Bilion) kepada Turki, memberi kelonggaran visa kepada rakyat Turki untuk berhijrah ke kawasan Schengen dan menerima penyelesaian ratio 1:1 membawa pelarian Syria kembali ke Turki daripada permohonan memasuki negara-negara EU. Amat ketara, peningkatan permohonan rakyat Turki yang mendadak untuk berhijrah tersebut telah menimbulkan persepsi negatif dan skeptisisme dalam kalangan warga EU serta mendorong penolakan terhadap perjanjian pelonggaran visa tersebut (Elmener, 2017).

Dimensi identiti-budaya pula menjelaskan bahawa Turki dikenali umum sebagai sebuah negara majoriti Muslim yang melaksanakan dasar-dasar pro-Uthmaniyah dan pro-Islami (Elmener, 2017). Hakikat ini merupakan sesuatu yang tidak dapat diterima oleh majoriti negara-negara EU. Beban sejarah yang dipikul Turki juga telah banyak meninggalkan memori perseteruan keagamaan khususnya antara Islam dan Kristian (Muftuler-Bac, 2007). Beberapa polemik dan perdebatan yang hangat dalam kalangan komuniti Eropah, telah dimainkan oleh kelompok haluan kanan. Antaranya persepsi kemungkinan dominasi Turki dalam Parlimen EU, perubahan lanskap politik dan sosial 
di Eropah, perang persepsi ketamadunan Islam melawan Barat serta isu penukaran Aya Sofia daripada muzium kepada masjid yang telah menajamkan lagi perselisihan antara Turki dan EU (Reuters, 2020). Sebahagian kelompok anti-Turki juga mendakwa bahawa Turki bukan sebahagian dari Eropah dan komuniti Eropah menolak wacana integrasi Turki ke dalam EU (Aksit, Senyuva \& Ustun, 2009).

Berdasarkan analisis senario terkini tersebut, segala ketidaktentuan dalam hubungan Ankara-Brussels tersebut amat bergantung kepada peranan semua aktor bagi memperbaiki hubungan kedua-dua pihak tersebut. Dalam konteks menganalisis peranan tersebut, penyelidik mengambil satu pendekatan yang bersifat strategik dan akomodatif dengan meninjau peranan badan - badan pemikir dalam mencorak wacana Ankara-Brussels, sumbangan idea, strategi serta inisiatif yang dijana bagi merangsang proses integrasi Turki dalam EU.

\section{Badan Pemikir: Satu Pengenalan}

Sebelum era milennium, kajian terhadap badan pemikir sebagai badan yang mempengaruhi proses membuat dasar kurang diberikan perhatian. Stone (2000) mendakwa bahawa badan pemikir merupakan fenomena yang telah dipinggirkan dalam kajian sains sosial. Pasca 2000, badan pemikir semakin berkembang dan perhatian terhadap badan pemikir semakin meningkat. Komuniti penyelidik dan cendekiawan semakin mendominasi ruang awam dalam bidang-bidang utama yang menyinggung soal kemasyarakatan dan kenegaraan. Peranan badan pemikir dalam proses memformulasikan dasar-dasar semakin relevan, signifikan dan sedang mengalami evolusi. Sebelumnya lebih low profile, kini ia semakin dominan, mandiri secara kewangan serta berpengaruh dalam pembangunan dasar-dasar.

Sherrington (2000) mentakrifkan badan pemikir sebagai organisasi yang bebas untuk mengaplikasikan penyelidikan dalam skop dan minat yang luas. Secara asas, tujuan utama badan pemikir adalah menyebarkan penyelidikan mereka seluas mungkin dengan hasrat untuk mempengaruhi proses pembikinan dasar. Menurut McGann (2012), badan pemikir berfungsi secara unik menerusi kajian dasar awam, khidmat nasihat, tidak membuat keuntungan serta "bebas" daripada campurtangan kerajaan atau parti politik. Fungsi utama badan pemikir juga termasuk membantu kerajaan memahami isu-su dan memandu membuat pilihan yang lebih tepat melalui maklumat dan kajian terperinci.

Badan pemikir memainkan peranan yang besar dalam menjana idea, analisis dan solusi melalui hasil proses percambahan idea dan penyelidikan; serta menasihati kerajaan dan pihak berkepentingan dalam perkara melibatkan dasar-dasar awam politik, ekonomi, sosial samada di peringkat domestik atau antarabangsa serta aktiviti outreach untuk menyebarkan maklumat kepada masyarakat umum. 
Jadual 1: Peranan Kritikal Badan Pemikir (Sumber: Safwan Saparudin, 2019)
a. Bertindak sebagai jambatan antara kerajaan dan rakyat awam bagi membina keyakinan terhadap penjawat awam;
b. Menyuarakan pandangan dan analisis secara berfakta, berobjektif dan kendiri dalam wacana dasar;
c. Mentafsir isu-isu, peristiwa dan dasar-dasar serta memudahcarakan domestik dan antarabangsa; penyampaian kefahaman kepada masyarakat awam berkaitan isu dan dasar
d. Menyediakan ruang dan platform untuk percambahan idea dan perkongsian maklumat antara pemegang taruh dalam proses formulasi dasar.

Sebahagian badan pemikir juga berfungsi sebagai pendesak dan pelobi. Siim Kallas, Naib Presiden Suruhanjaya EU mendesak agar badan-badan pemikir Eropah untuk melibatkan diri sebagai sukarelawan dalam senarai pelobi (Anon, 2009). Namun, Willis (2009) melaporkan sebahagian badan pemikir tidak mahu dikaitkan dengan aktiviti melobi dan enggan mendaftarkan diri. Begitu juga, Gilroy (2012) mendakwa bahawa mendidik pembuat dasar adalah berbeza dengan melobi mereka. Berdasarkan LobbyFacts, Google merupakan pelobi paling aktif di Brussels dengan lebih 120 pertemuan melibatkan Suruhanjaya EU, menteri kabinet dan ketua pengarah (tidak termasuk pegawai bawahan dan ahli parlimen).

Aktiviti-aktiviti yang dilaksanakan oleh badan pemikir melibatkan keseimbangan antara penyelidikan, analisis dan penyebaran kepada awam (outreach). Antaranya merangka isu-isu dasar; menyelidik dan menerbitkan buku, laporan, makalah, taklimat dasar (policy brief) dan monograf; menjalankan penilaian dalam program-program kerajaan; menyebarkan dapatan penyelidikan serta menganjurkan pelbagai aktiviti outreach seperti memberi taklimat kepada pemegang-pemegang taruh, muncul dalam media; menjalinkan rangkaian dan platform pertukaran idea melalui bengkel, seminar dan taklimat; dan memberikan sokongan kepada penjawat awam kanan sekiranya mereka tidak hadir ke sidang berkenaan.

Jumlah badan pemikir di setiap negara mengalami peningkatan yang signifikan. Menurut McGann (2020), terdapat lebih 8248 badan pemikir seluruh dunia. Daripada jumlah tersebut, 2219 berpusat di benua Eropah manakala 1871 berpusat di Amerika Syarikat. Bagi Nichelsen (2009), Amerika Syarikat mempunyai badan pemikir tertinggi dengan 1831 buah manakala Eropah memiliki lebih 1722 buah. Negaranegara lain seperti China (429), Turki (31), Palestin (44), Rusia (122), Korea Utara (4), Mesir (57), Iraq (42), Israel (59), Arab Saudi (7) dan Syria (6). Agak ironi bagi negara yang dilanda konflik seperti Mesir dan Palestin mempunyai lebih banyak badan pemikir berbanding negara yang lebih maju dan stabil seperti Arab Saudi dan Turki. Jadual 2 menunjukkan benua Eropah dan Amerika mendahului dari segi kuantiti badan pemikir di seluruh dunia. 
Jadual 2: Taburan Jumlah Badan Pemikir Di Seluruh Dunia (Sumber: Mcgann, 2020)

\begin{tabular}{ll}
\hline Rantau/Benua & Bilangan \\
Eropah & 2219 \\
Amerika Utara & 2058 \\
Asia & 1829 \\
Amerika Selatan \& Tengah & 1023 \\
Afrika Sub-Sahara & 612 \\
Timur Tengah dan Afrika Utara & 507 \\
Jumlah & 8248 \\
\hline
\end{tabular}

Sejak tahun 1980-an, banyak badan pemikir telah memilih pengkhususan bidang seperti dasar-dasar luar, pendidikan dan keselamatan. Badan pemikir ini lebih dikenali sebagai boutique think tank. Jadual 3 mengkategorikan beberapa bentuk badan pemikir berdasarkan pengkhususan bidang, jenis dan fungsi.

Jadual 3: Jenis-Jenis dan Bentuk Badan Pemikir yang Utama (Sumber: Safwan Saparudin, 2019)

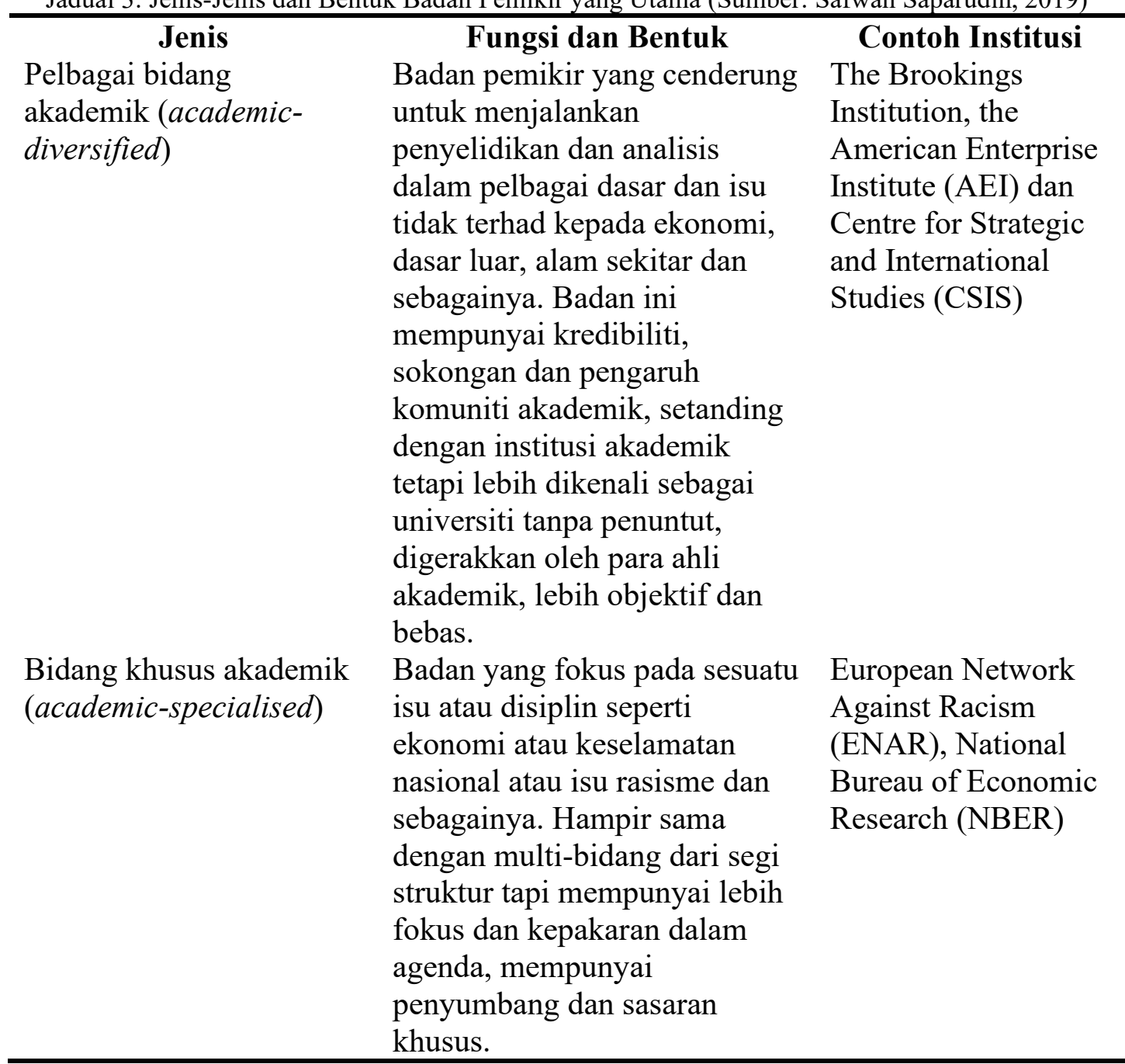




\begin{tabular}{|c|c|c|}
\hline $\begin{array}{l}\text { Penyelidikan/perundingan } \\
\text { secara kontrak (contract } \\
\text { research/consulting) }\end{array}$ & $\begin{array}{l}\text { Badan ini melaksanakan } \\
\text { penyelidikan dan analisis } \\
\text { untuk agensi-agensi kerajaan } \\
\text { yang mempunyai orientasi } \\
\text { dasar tertentu dan mempunyai } \\
\text { hubungan kerja yang rapat } \\
\text { dengan agensi kerajaan. Badan } \\
\text { ini bergantung kepada kontrak } \\
\text { dari kerajaan, bertindak } \\
\text { sebagai perunding program } \\
\text { dan dasar-dasar, menawarkan } \\
\text { analisis yang objektif dan } \\
\text { kuantitatif, menghasilkan } \\
\text { analisis dasar berbanding } \\
\text { penyelidikan, multi-bidang dan } \\
\text { mempunyai sistem ganjaran, } \\
\text { jadual penerbitan dan tertakluk } \\
\text { kepada perjanjian. }\end{array}$ & $\begin{array}{l}\text { RAND dan Urban } \\
\text { Institute. }\end{array}$ \\
\hline $\begin{array}{l}\text { Badan pemikir advokasi } \\
\text { (advocacy think tank) }\end{array}$ & $\begin{array}{l}\text { Badan pemikir yang } \\
\text { mempunyai sudut pandang, } \\
\text { moral dan ideologi tertentu dan } \\
\text { analisis yang kuat serta bersifat } \\
\text { partisan. Matlamat badan ini } \\
\text { diwujudkan untuk kepentingan } \\
\text { perjuangan, konstituensi, } \\
\text { ideologi, parti dan wadah. } \\
\text { Badan ini membawa isu dan } \\
\text { falsafah, menolak orientasi } \\
\text { akademik dan teknokratik } \\
\text { dalam analisis dasar. Kejayaan } \\
\text { diukur pada keupayaan } \\
\text { mencapai perjuangan }\end{array}$ & $\begin{array}{l}\text { Cato Institute dan } \\
\text { Citizens for a Sound } \\
\text { Economy. }\end{array}$ \\
\hline Policy Enterprise & $\begin{array}{l}\text { Kumpulan ini menumpukan } \\
\text { mempakej dan memasarkan } \\
\text { idea melalui keberkesanan } \\
\text { institusi korporat serta } \\
\text { menjalankan prinsip-prinsip } \\
\text { pengurusan, pemasaran dan } \\
\text { jualan khusus dalam } \\
\text { penyelidikan dasar awam. } \\
\text { Kebiasaannya badan ini } \\
\text { bergerak seperti syarikat } \\
\text { akhbar dan mempunyai jadual } \\
\text { penerbitan yang padat. }\end{array}$ & $\begin{array}{l}\text { Heritage Foundation } \\
\text { dan Economic Policy } \\
\text { Institute. }\end{array}$ \\
\hline
\end{tabular}


Badan pemikir juga berbeza antara sama lain berdasarkan status kemandirian sumber kewangan, independen daripada kerajaan dan tujuan kewujudan sama untuk keuntungan atau tidak. Jadual 4 menyenaraikan kategori badan pemikir berdasarkan ketiga-tiga aspek tersebut.

Jadual 4: Kategori Badan Pemikir Dan Definisi

\section{Kategori}

Autonomi dan Mandiri

Quasi mandiri

Kerajaan

Quasi Kerajaan

Universiti

Parti Politik

Korporat (Berasaskan

keuntungan)

\section{Definisi}

Mandiri dari kumpulan berkepentingan, sumbangan dan bantuan kerajaan.

Autonomi daripada kerajaan tetapi dikawalselia oleh kumpulan berkepentingan, penyumbang atau agensi yang menyalurkan majoriti dana serta memiliki pengaruh kepada operasi badan tersebut.

Sebahagian daripada struktur rasmi kerajaan.

Didanai secara khusus oleh geran kerajaan dan perjanjian, tetapi bukan sebahagian daripada struktur rasmi kerajaan.

Pusat penyelidikan dasar di universiti.

Sebahagian daripada struktur rasmi kerajaan.

Badan penyelidikan dasar awam berasaskan keuntungan, memiliki hubungan rasmi dengan syarikat-syarikat korporat dan bertujuan keuntungan.

\section{Badan Pemikir Dalam Dasar Luar Dan Hubungan Antarabangsa}

Pasca 1970-an, politik dunia mula terefleksi daripada peranan Badan Bukan Kerajaan (BBK). Keohane \& Nye (1972) mempersoalkan paradigma state-centric dan realisme dalam teori hubungan antarabangsa yang gagal mengiktiraf peranan BBK dalam pembangunan dasar luar dan menggariskan kepentingan-kepentingan peranan BBK termasuklah badan pemikir, syarikat multinasional, institusi keagamaan, gerakan revolusi, kesatuan sekerja dan jaringan saintis dalam bidang hubungan antarabangsa. Pasca kejatuhan Soviet Union tahun 1980-an, badan-badan pemikir mula mengambil posisi utama dalam arena pembikinan dasar luar. Badan-badan pemikir dalam bidang dasar luar dan hubungan antarabangsa umumnya diterajui bangsa Anglo-Amerika seperti Council on Foreign Relations (CFR), RAND dan Royal Institute of International Affairs (Chatham House) dan banyak lagi. Transformasi global mendorong penubuhan badan-badan pemikir ini berkembang ke benua dan rantau yang lain dengan lebih pantas lagi.

Hubungan akrab antara badan pemikir dan pakar bidang (subject matter expert) dalam memformulasikan dasar luar dianggap penting khususnya bagi membentuk lingkungan komuniti dasar (policy community) dan koalisi advokasi (advocacy coalition) yang lebih berkredibiliti. Literatur yang memperdebatkan pengaruh lingkungan badan pemikir dalam memformulasikan dasar-dasar juga semakin berkembang. Sebahagian 
sarjana menumpukan keupayaan membingkai perdebatan, mengenalpasti masalahmasalah dan membentuk persepsi-persepsi dasar yang mempengaruhi sistem-sistem politik, ekonomi dan sosial. Sebahagian lain menggariskan kepentingan badan pemikir dan interaksinya dengan jaringan dasar (policy network) kerana jaringan tersebut memadukan pemain-pemain samada dalam atau luar kerajaan untuk menyelaras proses membuat keputusan dan pelaksanaan, yang biasanya berlaku secara tidak formal dan lebih terbuka sifatnya (McGann, 2012).

Melalui jaringan tersebut juga, badan pemikir dapat menyumbangkan mutiara ilmiah dan bertindak sebagai usahawan dasar (policy entrepreneur) melalui pendekatan mempromosikan idea-idea berkenaan agenda-agenda kepentingan awam dan membina hubungan dalam kalangan pemegang taruh. Realitinya, kumpulan berkepentingan seperti agensi kerajaan, komuniti usahawan dan akademia lebih kerap berinteraksi dengan badan pemikir samada secara formal atau tidak formal kerana badan pemikir memiliki bank idea dasar-dasar dan memegang otoriti ilmu yang mampu mengangkat kredibiliti sesuatu dasar tersebut (McGann, 2012). Pihak media juga sering merujuk kepada badan pemikir kerana mereka amat dahagakan pencerahan, fakta serta komentar daripada pakar bidang. Secara langsung, badan pemikir berpeluang menyebarkan idea mereka melalui akhbar, radio, televisyen serta media sosial (McGann, 2012).

Umumnya, badan pemikir mempunyai hubungan strategik dan menganggotai komuniti badan pemikir yang tersendiri dalam proses melestarikan pasaran idea dalam penyelidikan dan pembangunan dasar. Dalam konteks EU, banyak institusi dan agensi berkaitan EU yang memanfaatkan pakar-pakar antarabangsa pelbagai bidang menerusi kerjasama pintar dengan badan-badan pemikir yang berpusat di universiti dan pusat penyelidikan. Dengan pertambahan negara-negara anggota EU, kuantiti dan kerumitan pembikinan dasar-dasar turut meningkat di Brussels dan negara-negara anggota EU. Fenomena ini merangsang kepada pertumbuhan badan pemikir dalam pelbagai bidang dan spektrum dasar-dasar kritikal terutamanya dasar luar, pertahanan dan keselamatan (McGann, 2012). Jadual 5 menunjukkan Amerika Syarikat mendominasi industri ini dari segi kuantiti, kualiti dan prestij.

Jadual 5: 10 Badan Pemikir Terkemuka Dalam Bidang Dasar Luar Dan Hal Ehwal Antarabangsa (Sumber: McGann, 2020)

\begin{tabular}{lll}
\hline & Nama Badan & Negara \\
1. & Brookings Institution & Amerika Syarikat \\
2. & Carnegie Endowment for International Peace & Amerika Syarikat \\
3. & French Institute of International Relations (IFRI) & Perancis \\
4. & Chatham House & Britain \\
5. & Center for Strategic and International Studies (CSIS) & Amerika Syarikat \\
6. & China Institutes of Contemporary International & China \\
& Relations (CICIR) & \\
7. & Wilson Center, FKA Woodrow Wilson International & Amerika Syarikat \\
\hline
\end{tabular}


Center for Scholars

8. Japan Institute of International Affairs (JIIA)

9. RAND Corporation

10. International Institute for Strategic Studies (IISS)
Jepun

Amerika Syarikat

Britain

\section{Badan Pemikir Dalam Wacana Turki-EU}

Dalam konteks penyertaan Turki dalam EU, salah satu instrumen yang signifikan bagi mengembangkan Soft Power Turki adalah menerusi pengaruh badan-badan pemikir. Peranan badan pemikir melalui penyelidikan, menyebarkan maklumat dan mempengaruhi persepsi pemegang - pemegang taruh serta rakyat umum umpama "minyak pelincir" dalam menjayakan matlamat strategik dasar luarnya. Tanpa penerbitan bahan maklumat dan sistem komunikasi yang berkesan, hasrat tersebut sukar menjadi realiti (Servantie, 2017).

Usaha-usaha penyelidikan berkaitan penyertaan Turki dalam EU semakin berkembang khususnya dalam kalangan komuniti institusi pemikir, universiti dan juga kementerian hal ehwal EU. Wacana dan isu-isu yang melatari hubungan Ankara-Brussels dibahaskan dalam seminar, forum, mesyuarat dan dialog politik tertinggi serta dibincangkan melalui saluran media utama dan media sosial. Komuniti akademik semakin "meriah" dengan perdebatan dalam wacana tersebut. Sebagai contoh, Jadual 6 menunjukkan kewujudan 14 badan pemikir yang menumpukan wacana hubungan Turki-EU di Turki. Sebahagiannya diwujudkan di bawah pusat penyelidikan universiti dan sebahagiannya ditubuhkan oleh kumpulan berkepentingan tertentu seperti dewan perniagaan atau pertubuhan berasaskan advokasi. Berdasarkan senarai tersebut, İKV merupakan badan pemikir paling tua dan paling berpengalaman dalam bidang hubungan Ankara-Brussels (Servantie, 2018).

Jadual 6: Badan-Badan Pemikir Dalam Wacana Turki-Eu Di Turki (Sumber: Safwan Saparudin, 2018)

Nama Badan Pemikir

Istanbul Policy Centre (IPC)

Foundation for Political, Economic

and Social Research (SETA)

Economic Development Foundation

(IKV)

Centre for Strategic Research (SAM)

Centre for Economics and Foreign

Policy Studies (EDAM)

International Strategic Reseach

Organisation (USAK)

Turkish Economic and Social Studies

Foundation (TESEV)

Center for Middle Eastern Strategic

\section{Lokasi}

Istanbul

Istanbul, Ankara,

Washington DC dan

Kaherah

Istanbul dan Brussels

1965

Ankara

1995

Istanbul

2005

Ankara

2004

Istanbul

1994

Tahun

Ditubuhkan

2001

2006

Ankara

2009 


\begin{tabular}{lcc}
\hline $\begin{array}{l}\text { Studies (ORSAM) } \\
\text { Turkey European Union Association } \\
\text { (TURABDER) }\end{array}$ & Istanbul, Sakarya & 1990 \\
$\begin{array}{l}\text { Institute of Strategic Thinking (SDE) } \\
\text { European Union Institute }\end{array}$ & Ankara & 2009 \\
$\begin{array}{l}\text { Wise Men Centre for Strategic Studies } \\
\text { (BILGESAM) }\end{array}$ & Istanbul & 1987 \\
$\begin{array}{l}\text { Eurasian Strategic Research Center } \\
\text { (ASAM) }\end{array}$ & Ankara & 2008 \\
\begin{tabular}{l} 
Strategic Outlook \\
\hline
\end{tabular} & Konya & 1999 \\
\hline
\end{tabular}

Jadual 7 menunjukkan beberapa nama badan pemikir yang utama berkaitan wacana Turki-EU di peringkat global dengan jumlah yang signifikan.

Jadual 7: Badan-Badan Pemikir Antarabangsa Berkaitan Wacana Turki-Eu. (Sumber: Safwan Saparudin, 2018)

\section{Nama Badan Pemikir}

Middle East Institute (MEI)

Carnegie Europe

Centre for Policy and Research on

Turkey (Research Turkey)

Chatham House

Centre for European Integration

Studies

Centre for Strategic and International

Studies (CSIS)

Centre for European Policy Studies

Council on Foreign Affairs (CFR)

\section{Lokasi}

Washington DC

Brussels

London

London

Germany

Washington DC

Brussels

New York,

Washington DC

\section{Tahun}

\section{Ditubuhkan}

1946

1910

2012

1920

1995

1987

1983

1921

Kerjasama dalam bentuk projek atau platform membantu merancakkan lagi wacana serta menggariskan saranan - saranan yang strategik. Pelaksanaan projek secara bersama ini dilihat berpotensi memupuk persahabatan pintar dan yang paling penting menjana hasil perbincangan yang berkualiti dan lebih komprehensif. Kerjasama tersebut dilihat sebagai usaha yang serius dan merentas tema-tema strategik lain seperti pembangunan, sosio-politik, kewangan, pelaburan dan sebagainya. Berdasarkan Jadual 8 , badan-badan pemikir menjalin kerjasama dengan pelbagai badan pemikir termasuk sektor kerajaan serta melaksanakan inisiatif-inisiatif strategik dalam kerangka wacana Ankara-Brussels. Projek-projek yang dilaksanakan umumnya menelan ribuan malah jutaan Euro dengan pembiayaan oleh Kesatuan Eropah sendiri. Menurut Baser (2017), permohonan geran pembiayaan oleh EU boleh mencecah 150,000 Euro dengan syaratsyarat yang ditetapkan. 
Jadual 8: Projek dan Platform Khas dalam Wacana Turki-EU (Sumber: FEUTURE, Kementerian Hal Ehwal Eropah, European Investment Bank, Turkey in Horizon 2020, Delegation of European Union to Turkey)

\begin{tabular}{|c|c|c|}
\hline Nama Projek/Platform & Penganjur Bersama/Rakan Kerjasama & $\begin{array}{l}\text { Tahun } \\
\text { Aktif }\end{array}$ \\
\hline FEUTURE & $\begin{array}{l}\text { University of Cologne, Istituto Affari } \\
\text { Internazionali (IAI), Istanbul Bilgi } \\
\text { University, Barcelona Centre for } \\
\text { International Affairs (CIDOB), Centre } \\
\text { international de formation européenne } \\
\text { (CIFE), Caucasus Research Resource } \\
\text { Center Georgia (CRRC), Danish Institute } \\
\text { for International Studies (DIIS), Centre for } \\
\text { Economics and Foreign Policy Studies } \\
\text { (EDAM), Hellenic Foundation for } \\
\text { European and Foreign Policy (Eliamep), } \\
\text { Koç University, Middle East Research } \\
\text { Institute (MERI), Middle East Technical } \\
\text { University (METU), Trans European } \\
\text { Policy Studies Association (TEPSA), } \\
\text { American University in Cairo dan Sabanc1 } \\
\text { University. }\end{array}$ & $\begin{array}{l}2016- \\
2019\end{array}$ \\
\hline A-NEST Academic & Delegasi Kesatuan Eropah ke Turki, & $2015-$ \\
\hline $\begin{array}{l}\text { European Union to } \\
\text { Turkey Network }\end{array}$ & $\begin{array}{l}\text { Ankara University, Yaşar University, } \\
\text { Sabancı University dan Bilgi University. }\end{array}$ & kini \\
\hline $\begin{array}{l}\text { Turkey in Horizon } 2020 \\
\text { Project }\end{array}$ & Kesatuan Eropah dan Republik Turki & 2016 \\
\hline $\begin{array}{l}\text { Bantuan Perusahaan } \\
\text { Kecil dan Sederhana } \\
\text { (PKS) }\end{array}$ & European Investment Bank & 2014 \\
\hline $\begin{array}{l}\text { Civil Society Dialogue } \\
\text { Between EU and Turkey } \\
\text { I-IV }\end{array}$ & Kesatuan Eropah dan Republik Turki & 2008-2009 \\
\hline $\begin{array}{l}\text { Jean Monnet Scholarship } \\
\text { Programme }\end{array}$ & Kesatuan Eropah dan Republik Turki & 1989-kini \\
\hline $\begin{array}{l}\text { Turkish Local Media on } \\
\text { the EU Path I-II Project }\end{array}$ & Kesatuan Eropah dan Republik Turki & $2011-2013$ \\
\hline $\begin{array}{l}\text { EUSG Young } \\
\text { Translators Competition }\end{array}$ & Republik Turki & 2010 \\
\hline $\begin{array}{l}\text { Support to Preparation of } \\
\text { the National Strategy for } \\
\text { Harmonization with the } \\
\text { EU Acquis in the Right } \\
\text { of Establishment and }\end{array}$ & Republik Turki & 2014 \\
\hline
\end{tabular}


Ringkasnya, badan pemikir bukan lagi menjadi aktor terpinggir dalam arus globalisasi. Sebaliknya, ia menjadi nadi yang penting dalam pembangunan dasar - dasar utama samada di peringkat domestik mahupun antarabangsa. Perkembangan badan pemikir sebagai aktor bukan kerajaan telah merancakkan proses pencerdasan dalam kalangan pembikin dasar, ahli politik, pemimpin, pengamal media serta masyarakat antarabangsa.

\section{Kajian Kes: İktisadi Kalkinma Vakfi}

Menyedari potensi pembangunan dan reformasi negara melalui integrasi Turki Eropah, Yayasan Pembangunan Ekonomi, Yayasan İktisadi Kalkınma Vakf (IKKV) telah ditubuhkan di Istanbul (Servantie, 2017). Sebagai badan pemikir yang tertua dan berpengalaman di Turki, İKVdianggap sebagai pakar rujuk dalam membantu mencapai misi dasar luar Turki untuk menganggotai Kesatuan Eropah menerusi pendekatan diplomatik khususnya melalui platform ekonomi, pendemokrasian dan penyelidikan. Semenjak 1960-an, pelbagai usaha yang signifikan telah digerakkan oleh İKV melalui penyelidikan, hubungan diplomatik, penerbitan dan gerakan melobi bagi mencapai objektif utama dasar luar kerajaan Turki (Servantie, 2018).

Sejarah penubuhan İKV bermula pada 26 November 1965, hasil initiatif dua organisasi gergasi dalam bidang perdagangan dan industri Turki iaitu Istanbul Chamber of Commerce dan Istanbul Chamber of Industry (Servantie, 2018). Dua tahun selepas termeterainya Perjanjian Ankara 1963 yang menandakan permulaan hubungan antara Turki dan Eropah, İKV mula menapak dalam wacana Ankara-Brussels. Diasaskan oleh tokoh-tokoh penting seperti Behçet Osmanağaoğlu, presiden Istanbul Chamber of Commerce (ITO) dan Fazil Zobu, Presiden Istanbul Chamber of Industry (ISO), İKV pada peringkat awal meletakkan misi bagi tujuan memantau dan menilai hubungan Ankara-Brussels, menyampaikan maklumat kepada rakyat umum dan mewakili komuniti bisnes Turki dalam negara-negara anggota EU (Servantie, 2018).

Dua dekad selepas penubuhan ibu pejabat di Istanbul, sebuah cawangan telah dibuka di Brussel pada tahun 1984 (Servantie, 2018). Pembukaan pejabat di Brussels menandakan komitmen İKV untuk menggapai (reachout) kumpulan sasarannya dan mengukuhkan misinya sejajar dengan matlamat hubungan Ankara-Brussels. Pada tahun 2016, IKKV telah menambah entiti pemegang-pemegang amanahnya termasuklah Union of Chambers and Commodity Exchanges of Turkey, Banks Association of Turkey, Turkish Exporters' Assembly, Turkish Confederation of Employer Associations, Istanbul Commodity Exchange, Turkish Chambers of Agriculture dan Istanbul Ready-Made Garment Exporters' Association. Sokongan yayasan dan wakil yang mewakili pelbagai organisasi dan syarikat terhadap İKV juga semakin meningkat. Ringkasnya, IKV mendapat dokongan yang kuat pelbagai pemegang taruh yang 
mempunyai kepentingan bersama dalam aspek ekonomi, perdagangan, sosial dan politik (Servantie, 2018).

Asasnya, İKV ditubuhkan untuk menjayakan matlamat dasar luar Turki. Tujuan-tujuan İKV dalam Jadual 9 menumpukan aspek pembangunan dan reformasi Turki melalui platform kerjasama, diplomatik dan persefahaman dengan mengambil EU sebagai rakan kongsi utama dan model rujukan (İktisadi Kalkınma Vakfi, 2016a).

Jadual 9: Tujuan-Tujuan Kewujudan IKV (Sumber: İKV, 2019)
a. Untuk menyumbang kepada pembangunan ekonomi dan sosial negara Turki;
b. Untuk melaksanakan aktiviti-aktiviti yang membantu Turki membina hubungan dengan negara lain, kumpulan ekonomi khususnya dengan EU;
c. Untuk menganjurkan seminar, persidangan, sidang panel dan pertemuan mesyuarat bagi menyampaikan maklumat kepada rakyat umum;
d. Untuk memastikan kerjasama dan penyelarasan di kalangan komuniti bisnes di Turki dan luar negara;
e. Untuk membentuk pandangan-pandangan terhadap hubungan Turki-EU melalui pengukuhan kerjasama dan memastikan pertukaran maklumat antara organisasi awam dan swasta;
f. Untuk memantau dan menilai perkembangan di EU dan memaklumkan rakyat awam berkaitan potensi dan kesan perubahan terhadap Turki; dan
g. Untuk mempromosikan Turki di luar negara.

Sejarah hubungan Ankara-Brussels bermula sejak 31 Julai 1959, selepas wujudnya Komuniti Ekonomi Eropah (EEC) pada tahun 1958, apabila Turki telah memohon menjadi anggota dalam EEC (Servantie, 2018). Rundingan yang berlangsung telah menghasilkan perjanjian Ankara, yang mengiktiraf keanggotaan Turki sebagai anggota bersekutu dalam EEC pada 12 September 1963. Dua tahun kemudian, pada tahun 1965, IKV ditubuhkan. Dengan termeterainya Protokol Tambahan (Additional Protocol) sebagai tambahan kepada Perjanjian Penyertaan (Association Agreement) 1973, hubungan Turki-Eropah semakin akrab. Di era Perdana Menteri Suleyman Demirel, jadual tarif pengurangan hak kastam barangan Turki yang memasuki pasaran EU telah diubahsuai supaya lebih bersalingan atau timbal balik (reciprocal). Ketika itu, İKV meminta sebuah firma British untuk membuat kajian analisis impak terhadap Perjanjian Persekutuan sebagai usaha mengharmonisasi dengan EU. Di era itu, IKKV telah merintis jalannya dalam situasi tiada mana-mana pertubuhan yang mempunyai keupayaan dalam projek integrasi Turki-Eropah tersebut (Servantie, 2017).

Pada tahun 1974, hubungan antara Turki-Eropah mengalami kebuntuan akibat intervensi tentera Turki di kepulauan Cyprus apabila Turki menggunakan hak penjamin di pulau tersebut. (Servante, 2018). Di bawah arahan Perdana Menteri Bulent Ecevit menghantar tentera untuk melindungi Turki Cypriot daripada ancaman kumpulan pengganas EOKA-B diketuai Nikos Sampson terhadap pemimpin Cypriot Archbishop 
Makarios di Nicosia. Ketika itu, İKV menetapkan pendiriannya menyokong kerajaan Turki tetapi mengambil sikap lebih proaktif dengan membuka saluran dialog dan komunikasi dengan EEC setiap masa. Sikap tidak membelakangi saluran rasmi serta menjaga hubungan baik dengan EEC merupakan pendekatan yang tidak asing bagi İKV. Ini selari dengan pendirian İKV sebagai moderator yang sentiasa mengingatkan kepentingan hubungan akrab dengan EU.

Tahun 1980-an hubungan Turki-Eropah membeku seketika akibat peristiwa kudeta tentera di Turki pada tahun 1980 sehingga proses demokrasi dikembalikan pada tahun 1982 apabila Turgut Ozal dilantik sebagai Perdana Menteri (Servantie, 2018). Brussels mengkritik Ankara secara agresif khususnya isu pelanggaran hak asasi manusia dan demokrasi. Dalam hal ini, IKV melalui pejabatnya di Brussels telah mengambil langkah perlu bagi memujuk pihak Eropah mengekalkan hubungan akrab dan meneruskan proses rundingan penyertaan Turki dalam Eropah. Suruhanjaya EU, Émile Noël menasihati Ankara agar mengusahakan langkah pendemokrasian dan memartabatkan hak asasi manusia dengan lebih berkesan. Noël antara pimpinan EU yang "bekerja keras" untuk merapatkan hubungan Turki dan EU sebagaimana Noël (1988) menyebutkan dalam ucapannya:
"Selama 30 tahun berkhidmat dalam Suruhanjaya...saya telah bekerja.... Menyumbang kepada usaha mendekatkan Turki dengan komuniti EU."

Menurut Haluk Nuray, perwakilan İKV di Brussels, IKKV telah dilihat sebagai penghubung istimewa oleh Suruhanjaya Eropah dan Setiausaha Agungnya Émile Noël (yang berkhidmat pada 1958-1987) (Servantie, 2018). Noël merupakan warga Perancis yang lahir dari keturunan Belgium di Istanbul pada tahun 1922. Beliau memahami bahasa dan adat budaya Turki serta memainkan peranan utama menasihati pegawai IKKV dalam usaha menubuhkan perwakilan di Brussels, khususnya peluang mengenali institusi - institusi EU dan mempromosi kepentingan Turki di Eropah.

Pada tahun 1987, Turki telah memohon sebagai anggota penuh Komuniti Ekonomi Eropah (EEC), namun menemui kegagalan (Servantie, 2018). Kesatuan Eropah (EU) ditubuhkan pada 1 November 1993 oleh Jerman, Perancis, Belgium, Itali, Belanda dan Luxemberg. Beberapa tahun kemudian, Turki diiktiraf sebagai calon anggota EU dalam Sidang Kemuncak Majlis Eropah pada tahun 1999. Pengiktirafan tersebut merupakan satu pencapaian yang dibanggakan oleh IKV hasil aktiviti melobi dalam pelbagai siri rundingan. İKV terlibat langsung memuktamadkan perjanjian kesatuan kastam (customs union) pada tahun 1995 hasil siri rundingan melalui kerjasama rasmi dengan kerajaan Turki. Ini membuktikan peranan IKKV tidak asing lagi dalam wacana TurkiEU tersebut.

Melalui perwakilan İKV pertama di Brussels, İKV berhasil menyuburkan hubungan langsung dengan Eropah. Peranan susuk bernama Dr. Hayri Ürgüplü amat signifikan 
dalam memacu interaksi dan keakraban antara Turki dan Eropah (Servantie, 2018). Beliau yang mempunyai darah bangsawan merupakan anak lelaki kepada mantan perdana menteri Turki Suat Hayri Ürgüplü dan cucunda kepada ulama' empayar Uthmaniah. Kerjayanya sebagai diplomat, ilmuwan serta kepakarannya dalam bidang diplomasi, protokol dan prosedur EEC telah menjadi aset penting dan melonjakkan prestij İKV sepanjang 11 tahun perkhidmatannya sehingga tahun 1995. Ürgüplü juga berpengaruh dalam kalangan komuniti bisnes Turki di Brussels dan juga pemain utama hubungan Turki-Eropah pada era tersebut. Kenalan peribadi Ürgüplü dengan gergasi perniagaan seperti Rahmi Koc (Koc Holdings) misalnya menjadi faktor kerancakan usaha-usaha mempromosi perdagangan Turki di Eropah Ürgüplü meninggal dunia pada tahun 2017 di Belgium selepas sekian lama mengidap penyakit (Bardakci 2017). Walaubagaimanapun, pada tahun 1989 Suruhanjaya EU menyatakan respon negatif terhadap permohonan Turki ekoran rekod-rekod buruk dalam sektor hak-hak asasi dan ekonomi serta pencapaian yang rendah berbanding negara-negara Eropah yang lain (Servantie 2018). Ekoran itu, Ürgüplü mengukuhkan lagi usaha mempromosi permohonan Turki dalam siri mesyuarat dengan pegawai-pegawai EU. Kemudian dengan kemasukan Haluk Nuray mengetuai wakil İKV di Brussels pada tahun 1995, peranan İKV semakin diperkukuhkan khususnya dalam rundingan Customs Union. Nuray merupakan penjawat awam dalam Kementerian Perdagangan di Ankara dan memiliki pengetahuan luas dalam bidang perdagangan antara Turki dan EU. Nuray menumpukan aktiviti melobi pada tahun 1999 apabila Turki diiktiraf sebagai calon anggota rasmi EU dalam Sidang kemuncak Helsinki dan seterusnya rundingan keanggotaan pada 2005 (Servantie, 2018).

Menurut Haluk Nuray, İKV berbeza daripada organisasi pemikir lain kerana asas penubuhan serta semangatnya merintis jalan yang penuh onak berduri (Servantie, 2018). Beliau menambah, İKV memiliki perspektif lebih global dalam hubungan dengan EU dan tidak terhad dalam sesuatu sektor tetapi mampu menghasilkan saranansaranan dan pendirian yang signifikan dalam pelbagai isu (Servantie, 2018). Keupayaan ini terhasil daripada pendirian İKV yang apolitikal, menjauhi pendekatan terlalu politikal dan aktif sebagai penghubung dan mediator.

Seorang lagi susuk utama İKV pada era 1990-an adalah Pengerusi IKV, Jak Kamhi seorang usahawan berpengaruh dan pemilik Profilo Holdings (Servantie, 2018). Beliau mahir berbahasa Perancis dan sangat akrab dengan pegawai dan birokrat Komuniti Eropah (EEC). IKKV menghantar pasukan untuk mengunjungi negara-negara anggota EEC untuk menyebarkan kesedaran dan informasi berkenaan İKV di Eropah dan menilai potensi mewujudkan pejabat perwakilan di Brussels.

Dengan pengiktirafan Turki sebagai calon anggota EU pasca tahun 1999, hubungan Ankara-Brussels dilihat semakin subur (Servantie, 2018). Peranan İKV dilihat semakin diperlukan bukan hanya memperkenalkan Turki kepada EU tetapi juga "memujuk" rakyat Turki menjayakan projek penyertaan Turki dalam EU. İKV mengembangkan idea kemakmuran EU melalui penerbitan majalah bulanan serta penganjuran seminar, 
mesyuarat dan persidangan khas. Antara tahun 1999 dan 2005, IKKV melaksanakan pelbagai aktiviti yang penting dan menunjukkan perkembangan baik di Brussels. Pada 17 Disember 2004, ketua-ketua negara dan kerajaan EU memutuskan pintu rundingan keanggotaan dibuka secara rasmi pada 3 Oktober 2005 (Servantie 2018). Pencapaian tersebut membuka lembaran baru bagi Ankara-Brussels, hubungan kompleks dan sentiasa menarik perhatian masyarakat awam Turki dan juga EU. Pasca 2005, İKV berusaha keras untuk memperkenalkan Turki dan melonjakkan imej dan reputasinya dalam kalangan elit EU. Wakil İKV di Brussels menjadi "barisan hadapan" dalam usaha-usaha tersebut hasil hubungan akrab dengan pelbagai institusi EU.

\section{Peranan İKV Berdasarkan Taksonomi Diplomasi Awam}

Taksonomi dasar awam dikemukakan oleh Cull (2008) sebagai proses-proses kunci yang diperlukan oleh mana-mana badan berkepentingan untuk memenuhi matlamat dasar luarnya melalui libaturus dengan rakyat asing (foreign public). Taksonomi tersebut merujuk kepada lima komponen seperti mendengar, advokasi, diplomasi pertukaran, diplomasi kebudayaan dan penyiaran antarabangsa.

Pertama, mendengar (listening) yang merupakan aktiviti dasar awam paling asas bagi mendapatkan data, isu serta cadangan sumbangsaran pihak-pihak berkepentingan sebelum sesuatu strategi atau dasar dijana. Pendekatan yang dilaksanakan merangkumi bancian (survey), seminar, dialog dan sebagainya. Kedua, advokasi (advocacy) adalah satu langkah ke hadapan dengan memperjuangkan idea, gagasan dan dasar kepada pihak-pihak bersasar agar difahami dan diterima. Pendekatan dalam tahapan ini memanfaatkan pertemuan khusus, mesyuarat, seminar, jelajah (roadshow) dan penerbitan bahan bercetak dalam bentuk cetakan dan secara atas talian (online) dan edaran video (Cull, 2008).

Ketiga, diplomasi kebudayaan mempromosi secara satu hala nilai kebudayaan yang dimiliki kepada pihak bersasar. Dalam konteks ini, aktiviti yang dijalankan merangkumi pesta, tayangan filem, pertunjukan kesenian dan upacara kebudayaan. Keempat, diplomasi pertukaran (exchange diplomacy) melibatkan program diplomasi yang diadakan di negara-negara bersasar seperti Brussels dimana badan-badan utama Kesatuan Eropah beroperasi samada meletakkan pejabat khas atau menjalankan aktiviti jangka masa sederhana dan pendek bertujuan untuk membina kesefahaman, menyampaikan maklumat, bertukar-tukar idea dan kegiatan melobi. Kelima, penyiaran antarabangsa (international broadcasting) merujuk kepada menerbitkan maklumat khusus kepada pihak bersasar melalui video, bahan bercetak, atas talian khususnya menyampaikan maklumat, membetulkan salahfaham serta mempengaruhi fikiran (Cull, 2008). Jadual 10 menunjukkan beberapa program dan inisiatif İKV antara tahun 2005 dan 2020 yang telah menepati empat taksonomi diplomasi awam. Atas sebab kurang relevan, komponen diplomasi kebudayaan tidak dimasukkan dalam jadual tersebut. 
Jadual 10: Program dan Inisiatif İKV berdasarkan Taksonomi Diplomasi Awam (Sumber: İKV, 2018)

\begin{tabular}{|c|c|c|c|}
\hline Taksonomi & 2005-2009 & 2010-2014 & $2015-2020$ \\
\hline $\begin{array}{l}\text { Mendengar } \\
\text { (Listening) }\end{array}$ & $\begin{array}{l}\text { (a) "Visa } \\
\text { Hotline Project" } \\
\text { dilancarkan oleh } \\
\text { İKV, TOBB dan } \\
\text { European } \\
\text { Citizen Action } \\
\text { Service (ECAS) } \\
\text { untuk } \\
\text { mendapatkan } \\
\text { input, } \\
\text { membentangkan } \\
\text { dan } \\
\text { membincangkan } \\
\text { isu-isu dan } \\
\text { cabaran } \\
\text { berkenaan } \\
\text { proses } \\
\text { permohonan } \\
\text { visa, dokumen } \\
\text { dan di kalangan } \\
\text { komuniti } \\
\text { usahawan, } \\
\text { akademia, } \\
\text { pelajar dan } \\
\text { masyarakat } \\
\text { awam. } \\
\text { (b)İKV } \\
\text { menganjurkan } \\
\text { program dialog } \\
\text { bertemakan } \\
\text { "European } \\
\text { Parliamentarian } \\
\text { s and Turkish } \\
\text { Civil Society: } \\
\text { Dialogue for } \\
\text { Better } \\
\text { Understanding } \\
\text { Each Other" } \\
\text { yang }\end{array}$ & $\begin{array}{l}\text { (a)Menteri Hal Ehwal } \\
\text { Eropah dan Ketua } \\
\text { Perunding, Volkan } \\
\text { Bozkır bertemu dengan } \\
\text { Lembaga Pengarah İKV } \\
\text { bagi membincangkan } \\
\text { perkembangan terbaru } \\
\text { hubungan Turki-EU di } \\
\text { bawah kerangka "Turki } \\
\text { Baharu". } \\
\text { (b)Kaunselor Seksyen } \\
\text { Perdagangan, Ekonomi } \\
\text { dan Pertanian dari } \\
\text { Delegasi Kesatuan } \\
\text { Eropah ke Turki telah } \\
\text { mengadakan lawatan ke } \\
\text { IKV membincangkan isu } \\
\text { Turkey-EU Customs } \\
\text { Union, TraBBKtlantic } \\
\text { Trade and Investment } \\
\text { Partnership (TTIP), } \\
\text { liberalisasi visa dan } \\
\text { hubungan Turki-EU. }\end{array}$ & $\begin{array}{l}\text { (a)İKV } \\
\text { menganjurkan } \\
\text { forum bertajuk } \\
\text { "Turkey-EU } \\
\text { Relations, } \\
\text { Customs Union } \\
\text { and Financial } \\
\text { Cooperation". } \\
\text { (b)İKV } \\
\text { menganjurkan } \\
\text { seminar } \\
\text { membincangkan } \\
\text { "Turkey's Role } \\
\text { as a European } \\
\text { and Regional } \\
\text { Hub? } \\
\text { Implications for } \\
\text { Euro- } \\
\text { Mediterranean } \\
\text { Relations". } \\
\text { (c)İKV dengan } \\
\text { kerjasama } \\
\text { Yayasan } \\
\text { Friedrich } \\
\text { Naumann } \\
\text { menganjurkan } \\
\text { siri pertemuan } \\
\text { dengan } \\
\text { masyarakat } \\
\text { awam } \\
\text { membincangkan } \\
\text { inti penerbitan } \\
\text { laporan } \\
\text { "Linguistics of } \\
\text { Progress" di } \\
\text { beberapa buah } \\
\text { universiti di } \\
\text { Turki dan }\end{array}$ \\
\hline
\end{tabular}


menghimpunka

$\mathrm{n}$ masyarakat

madani dan 20

ahli-ahli

Parlimen

Kesatuan

Eropah.

(c)İKV

melaksanakan

siri seminar di

bawah projek

Window to

Turkey, yang

bertujuan

membincangkan

perkembangan

Turki-EU

khususnya dari

segi politik,

ekonomi dan

sosial

melibatkan

pakar-pakar dan

pemimpin

masyarakat

madani,

bertempat di

Brussels.
Brussels.

(d)íKV dengan

kerjasama

Dewan Industri

Eskisehir

menganjurkan

forum terbuka

bertajuk "Latest

Agenda of

Turkey-EU

Relations".

\begin{tabular}{|c|c|c|c|}
\hline $\begin{array}{l}\text { Advokasi } \\
\text { (Advocacy) }\end{array}$ & $\begin{array}{l}\text { (a)İKV } \\
\text { menganjurkan } \\
\text { projek "The EU } \\
\text { Civil Society } \\
\text { Dialogue : } \\
\text { Europe - Bridge } \\
\text { of Knowledge } \\
\text { Programme bagi } \\
\text { tujuan } \\
\text { mengukuhkan } \\
\text { pemantauan } \\
\text { dalam } \\
\text { memenuhi }\end{array}$ & $\begin{array}{l}\text { (a)Pengerusi IKV } \\
\text { mengadakan pertemuan } \\
\text { dengan Pesuruhjaya } \\
\text { European Neighbourhood } \\
\text { Policy and Enlargement } \\
\text { Negotiations, Johannes } \\
\text { Hahn. } \\
\text { (b)iKV mengadakan } \\
\text { kunjungan hormat ke } \\
\text { Kementerian Hal Ehwal } \\
\text { Kesatuan Eropah di } \\
\text { Ankara bagi }\end{array}$ & $\begin{array}{l}\text { (a)İKV } \\
\text { menerbitkan } \\
\text { laporan berjudul } \\
\text { "Current } \\
\text { Developments in } \\
\text { Agricultural } \\
\text { Sector in Turkey } \\
\text { and the EU". } \\
\text { (b)İKV } \\
\text { menerbitkan } \\
\text { laporan berjudul } \\
\text { "The Populist }\end{array}$ \\
\hline
\end{tabular}


syarat acquis communautaire khususnya sektor ekonomi yang melibatkan komuniti sektor ketiga bertempat di Istanbul.

(b)IKKV melaksanakan "projek ABC", satu program kesedaran melibatkan para guru dan pelajar sekolah terhadap projek integrasi TurkiEU, salahfaham dalam kalangan rakyat Turki serta impak keanggotaan Turki dalam EU.

(c)İKV dan TOBB menganjurkan "Seminars on Turkey's EU Pre-accession Process" di 24 buah bandar di seluruh Turki bagi meningkatkan kesedaran proses keanggotaan Turki dalam EU dengan membincangkan tentang proses dan perkembangan keanggotaan Turki dalam EU.

(c)İKV dan TOBB

mengadakan mesyuarat

sarapan pagi bersama duta Itali di Turki serta duta-duta Eropah bagi membincangkan projek integrasi Turki-Kesatuan Eropah.
Radical Right in Germany: Ideology \& Policies of Alternative Für Deutschland (AfD)" 
sokongan

kerajaan

tempatan,

universiti, institusi

kerajaan dan

masyarakat

madani.

\begin{tabular}{|c|c|c|}
\hline $\begin{array}{l}\text { Diplomasi } \\
\text { Pertukaran } \\
\text { (Exchange } \\
\text { Diplomacy) }\end{array}$ & $\begin{array}{l}\text { İKV dan Centre for } \\
\text { Strategic Research } \\
\text { (SAM) menyertai } \\
\text { mesyuarat di Suruhanjaya } \\
\text { Kesatuan Eropah, } \\
\text { Brussels bagi } \\
\text { membincangkan } \\
\text { "Communication, trust } \\
\text { and credibility in Turkey- } \\
\text { EU Relations", isu } \\
\text { Cyprus dan Customs } \\
\text { Union. Dibawah } \\
\text { kerangka "Windows to } \\
\text { EU" }\end{array}$ & $\begin{array}{l}\text { (a)İKV } \\
\text { menganjurkan } \\
\text { latihan "Future } \\
\text { Values" dengan } \\
\text { kerjasama } \\
\text { European } \\
\text { Neighbourhood } \\
\text { Council, } \\
\text { Friedrich } \\
\text { Naumann } \\
\text { Foundation and } \\
\text { General } \\
\text { Consulate of } \\
\text { Sweden. } \\
\text { (a)IKKV } \\
\text { menganjurkan } \\
\text { persidangan di } \\
\text { Romania } \\
\text { membincangkan } \\
\text { "EU } \\
\text { Presidencies and } \\
\text { Turkey". }\end{array}$ \\
\hline $\begin{array}{l}\text { Penyiaran } \\
\text { Antarabangsa } \\
\text { (International } \\
\text { Broadcasting } \\
\text { ) }\end{array}$ & $\begin{array}{l}\text { (a)İKV menerbitkan } \\
\text { sebuah video } \\
\text { dokumentari berbahasa } \\
\text { Inggeris sempena } \\
\text { sambutan İKV ke-40, } \\
\text { yang menyorot tujuan, } \\
\text { aktiviti dan } \\
\text { perkembangan İKV } \\
\text { dalam menjayakan } \\
\text { integrasi Turki-EU. }\end{array}$ & $\begin{array}{l}\text { (a)İKV } \\
\text { menyiarkan siri } \\
\text { webinar secara } \\
\text { langsung dalam } \\
\text { talian yang } \\
\text { mensasarkan } \\
\text { warga Eropah } \\
\text { dalam pelbagai } \\
\text { topik utama } \\
\text { seperti isu }\end{array}$ \\
\hline
\end{tabular}


(b)İKV dengan sokongan Delegasi Turki ke EU mewujudkan laman web mikro khusus menjelaskan dan menjawab 33 salahfaham dalam projek integrasi Turki-EU melalui pautan https://dby.İKV.org.tr/en/
Customs Unions, visi Eropah dan multilingualisme , krisis pandemik dan kesan kepada sektor ekonomi dan social EU dan hubungan TurkiEU.

Servantie (2018) mendapati integrasi Ankara-Brussels menunjukkan kemajuan berdasarkan kewujudan platform dan jawatankuasa utama dalam hubungan Turki-EU. Antaranya İKV menganggotai Meja Bulat Industrialis Eropah (European Roundtable of Industrialists) dan Turkey-EU Joint Consultative Commitee (JCC). JCC dianggotai oleh 18 wakil badan masyarakat madani dan badan bukan kerajaan (BBK) dari seluruh Eropah manakala 18 lagi diwakili oleh BBK dari Turki. Antara BBK dari Turki yang lain termasuklah TOBB (Union of Chambers and Commodity Exchanges of Turkey), TISK (Turkish Employers Association) dan Banks Association of Turkey as representatives of the employers, Türk-İş, Memursen, Hak-İş, KamuSen, TZOB (Union of Turkish Chambers of Agriculture), TESK (Confederation of Turkish Tradesmen and Craftsmen), KAGIDER (Women Entrepreneurs Association of Turkey) dan Turkish International Industrial Relations Association. Turki-EU JCC, sebagai sebuah jawatankuasa rundingan antara Turki dan EU telah ditubuhkan pada 1995 atas mandat Perjanjian Ankara yang telah melincirkan rundingan keanggotaan Turki dalam EU serta menjana saranan-saranan dan membina interaksi dalam kalangan masyarakat madani di Turki dan EU (European Economic and Social Committee, 2019). Melalui JCC ini, anggota-anggotanya berperanan sebagai promoter dan pendokong utama misi keanggotaan Turki dalam EU dan menyumbang secara signifikan dalam mengukuhkan hubungan antara Turki dan EU melalui bimbingan yang berterusan dan konkrit dalam isu-isu yang saling berkepentingan seperti hak-hak kesatuan sekerja, peranan wanita di Turki dan kerjasama perdagangan (European Economic and Social Committee, 2019).

Sejak rundingan keanggotaan bermula pada tahun 2004, İKV sebagai badan pemikir dan pelobi melaksanakan langkah-langkah strategik untuk merangsang momentum hubungan Ankara-Brussels dan meningkatkan kesedaran rakyat Turki sendiri (Servantie 2018). Antaranya, menyalurkan maklumat kepada agensi dan badan utama EU; menyusun program, kerjasama dan lawatan pihak berkepentingan dan otoriti EU ke Turki; menubuhkan "Platform Turki" bagi mengumpulkan lebih 250 badan bukan kerajaan (BBK) Turki untuk menyokong keanggotaan Turki-EU; dan menjalinkan hubungan dalam proses harmonisasi dengan sektor awam daripada Suruhanjaya 
Kesatuan Eropah, parlimen serta sektor swasta, badan-badan bukan kerajaan dan media antarabangsa.

Sebagai enjin utama yang aktif melaksanakan misi strategik dasar luar AnkaraBrussels, İKV telah melalui pengalaman yang panjang dan menyumbang secara konsisten sejak penubuhannya. Perjalanan diplomasi Turki-EU tidak lengkap tanpa peranan IKKV yang telah membantu menyuntik wacana dan turut serta menjana strategi kepada kerajaan Turki. Ini dibuktikan melalui dokumen rasmi, berita dan acara penting melibatkan Turki dan EU. Peristiwa dan tindakan dasar yang berkaitan kerajaan Turki dan EU mendapat perhatian yang serius dan kritikal oleh IKV lalu diterjemahkan melalui analisis dan penerbitan (Servantie, 2018).

Dengan moto organisasinya, pakar 'Kesatuan Eropah' Turki (Turkey's EU Expert), IKV mencapai tandaaras sebagai sebuah organisasi yang berpengalaman, kompeten dan berpotensi untuk menjayakan misi dasar luar Turki yang berusia lebih 50 tahun (Servante 2018). Secara dasarnya, İKV tidak menerima bantuan kewangan daripada kerajaan Turki sebaliknya mendapat sokongan padu daripada sektor swasta khususnya usahawan dan industri. Sebagai badan pakar yang berkecuali dan tidak terikat dengan kerajaan, İKV bebas mengeluarkan pandangan, kritikan dan penilaiannya khusus dalam hubungan Turki-EU.

Perjalanan integrasi Turki-EU tidak sunyi dengan onak duri dan ditaburi periuk api (Lecha, 2019). Hubungan Ankara-Brussels sentiasa hangat diperdebatkan, berliku dan kompleks (Tocci, 2014). Semenjak tahun 2016, hubungan mereka masih terperangkap dalam polemik akibat krisis migrasi, isu Cyprus, Islamofobia, kebangkitan kelompok haluan kanan, isu domestik Turki sendiri dan macam-macam lagi. Proses komunikasi melalui aktiviti -aktiviti libaturus seperti siri mesyuarat, kolokium dan persidangan seringkali menemui keadaan sukar, tegang dan rumit. Namun, melalui aktiviti tersebut, ruang kerjasama sentiasa terbuka dan berpotensi untuk memupuk saling kesefahaman. Servantie (2017) percaya peranan İKV mengkoordinasi hubungan dan wacana TurkiEU mewakili sektor swasta dilihat telah menyemarakkan kesedaran dalam kalangan EU dan rakyat Turki sendiri serta menunjukkan komitmen Turki menyempurnakan semua pra-syarat EU Acquis. Banyak ruang telah diterokai dan sebahagiannya telah membuahkan berhasil seperti perjanjian Customs Union antara Turki dan EU. Dalam konteks ini, pelbagai pihak mempunyai peranan untuk menentukan dan menjayakan apa juga Hasrat Bersama (shared vision) demi kepentingan rakyat dan pembangunan negara.

\section{Hasil Analisis Impak Terhadap İKV}

Dalam analisis impak terhadap peranan İKV, penyelidik merumuskan empat impak utama yang diusahakan oleh IKKV. Dalam analisis impak ini, penyelidik membataskan pentaksiran dalam kerangka diplomasi awam sesuai dengan peranan İKV sebagai aktor bukan kerajaan dalam memajukan tanggungjawab advokasi dasar luar Turki. 


\section{Pertama: IKV Meningkatkan Kefahaman Terhadap Identiti, Dasar Dan Nilai Turki}

Analisis impak bagi mengukur peningkatan kefahaman kumpulan sasaran terhadap identiti, dasar dan nilai Turki amat penting kerana ia adalah asas kepada penerimaan warga asing khususnya Eropah terhadap Turki. Sebagai salah sebuah agen diplomasi awam, IKV menetapkan untuk membina kefahaman komuniti Eropah berkenaan identiti, dasar dan budaya Turki seperti yang termaktub dalam objektif İKV. Melalui orientasi dan inisiatif yang digerakkan oleh İKV, proses tersebut kelihatan telah dan sedang berlaku berdasarkan output dan hasil kerja yang telah dibincangkan dalam bahagian dua sebelum ini. Terdapat tiga proses utama yang memacu impak ini iaitu (1) penyebaran maklumat, (2) penerimaan maklumat dan (3) pemahaman maklumat (Matwiczak, 2010).

Penyebaran maklumat merujuk kepada aktiviti yang dilaksanakan supaya maklumat dapat disampaikan tepat kepada sasaran menggunakan maklumat yang sesuai. Contoh aktiviti dan inisiatif tersebut termasuklah risalah, aktiviti kebudayaan, kelas kemahiran/bahasa, forum, bahan pendidikan di pusat maklumat, majlis yang dihadiri diplomat dan; program pertukaran kebudayaan, profesional dan pendidikan. İKV dalam perlembagaannya, menggariskan salah satu objektif penubuhannya adalah menyumbang untuk mempromosikan Turki ke luar negara. Atas kapasiti sebagai sebuah yayasan dan badan bukan kerajaan yang mengkhususkan advokasi menjayakan misi strategi luar negara Turki, İKV secara langsung dan tidak langsung memperkenalkan identiti, nilai-nilai dan dasar -dasar Turki kepada Eropah (Servantie, 2018).

Dalam mentaksirkan impak penyebaran maklumat, penyelidik menilai apakah aktiviti atau inisiatif yang bersesuaian dilaksanakan oleh İKV untuk mencapai maklumat kepada sasarannya. Apakah metodologi paling tepat untuk menyampaikan mesej? İKV telah menentukan kumpulan sasarannya seperti pesuruhjaya dan institusi-institusi Kesatuan Eropah, menteri dan diplomat Eropah di Turki, Kementerian Luar Turki, sektor usahawan Turki di Eropah, akademia dan badan pemikir Eropah serta rakyat Turki dan komuniti Eropah. Setiap sasaran ditentukan objektif, pendekatan dan aktiviti libaturus yang sesuai. Misalnya, usaha advokasi kepada pimpinan Kesatuan Eropah dilaksanakan melalui mesyuarat dan dialog bertaraf tinggi (high-level dialogue) melibatkan pesuruhjaya Kesatuan Eropah, pegawai institusi EU, kementerian luar Turki dan wakil sektor perniagaan dan industri yang berkenaan.

Manakala perencanaan maklumat dalam kalangan akademia, penyelidik dan badan pemikir dilaksanakan dalam platform seminar, bengkel dan panel perbincangan yang turut dihadiri pembuat dasar, wakil kementerian, pensyarah dan pelajar universiti. Selain pertemuan fizikal, İKV menyampaikan maklumat dan mesejnya melalui penerbitan makalah, buletin bulanan, buku serta risalah. Penerbitan tersebut berkesan untuk kumpulan sasaran seperti akademia, agensi dan kementerian serta sektor industri yang mempunyai kepentingan dalam wacana Turki-EU. Dalam peringkat ini, amat 
penting İKV mengetahui perubahan kuantiti dasar - dasar yang diperbahaskan dalam aktiviti-aktiviti İKV (Servantie, 2017).

Langkah kedua pula, penerimaan maklumat oleh semua kumpulan sasaran. Langkah ini mengukur kuantiti yang menerima maklumat atau menyertai aktiviti yang dilaksanakan. Setelah İKV mensasarkan bentuk dan objektif aktiviti serta kumpulan sasaran, IKKV menentukan sasaran jumlah yang sepatutnya hadir atau menerima maklumat. Misalnya, bilangan peserta yang hadir dalam program seminar Turki-EU telah mencapai jumlah yang disasarkan oleh İKV (Servantie, 2017). Dalam webinar perbahasan isu konflik pelarian Syria misalnya, jumlah peserta yang turut serta telah mencapai sasaran atau masih gagal menarik penglibatan sasaran. Bagi mengukurnya, penganjur menganalisis perubahan yang ketara dalam aspek kehadiran dan penglibatan samada kesesuaian dan sasaran yang ditetapkan adalah berpadanan (matching).

Langkah ketiga, kefahaman daripada maklumat yang dibentangkan dalam aktiviti advokasi awam yang diterima kumpulan sasaran. Berdasarkan jumlah maklumat yang dihadam atau dimanfaatkan oleh kumpulan sasaran melalui aktiviti tersebut, ia akan membentuk tindakan, sikap dan percakapan. Ringkasnya, aktiviti dan inisiatif yang dilaksanakan berjaya membentuk output baru dalam proses advokasi diplomasi awam. Analisis perlu menentukan garis asas kefahaman kumpulan sasar sebelum pelaksanaan aktiviti dan inisiatif. Misalnya, dalam sambutan Hari Eropah peserta dinilai sebelum dan selepas aktiviti. Dalam program pertukaran pelajar Turki di Eropah pula, penganjur menilai pelajar tersebut sebelum dan selepas tamat program tersebut (Servantie, 2017). Diplomasi secara khusus, merupakan komunikasi antara kerajaan dan kerajaan. Diplomasi awam pula merujuk usaha advokasi dan komunikasi antara kerajaan dengan kelompok rakyat awam dan masyarakat yang disasarkan. Kumpulan sasaran utama dalam pentaksiran ini terbahagi kepada tiga; pegawai kerajaan, kumpulan elit dan rakyat awam (Servantie, 2017). Dalam hal ini, IKKV mensasarkan pegawai kerajaan khususnya pegawai-pegawai dalam Suruhanjaya Eropah yang terdiri daripada Pesuruhjaya, pengarah jabatan dan agensi sehingga kumpulan pakar dalam pelbagai sektor kerajaan. Kumpulan elit termasuklah ketua dan penggerak utama dalam sektor politik, budaya, agama, sosial dan perniagaan. Ini adalah sasaran utama İKV seperti badan pemikir, universiti, pertubuhan bukan kerajaan dan dewan perniagaan. Rakyat awam pula tertumpu kepada komuniti Eropah secara umum dan rakyat Turki sendiri.

Menurut Servantie (2017), İKV berjaya mendapat akses secara langsung dengan agensi EU melalui mesyuarat dan aktiviti libaturus (engagement) untuk menyatakan dan bertukar-tukar saranan idea dan dasar pembaharuan atas kepentingan Turki dan EU. Pegawai-pegawai EU mengiktiraf peranan aktif dan sumbangan IKKV sebagai satu nilai tambah dalam projek pembesaran (enlargement) EU. Servantie (2017) mendakwa hubungan IKKV dengan sektor badan pemikir dan perniagaan di Eropah adalah sangat lama berdasarkan tradisi dan peranannya sejak penubuhan IKKV tahun 1965. Ini terbukti dalam siri seminar, webinar dan mesyuarat utama yang melibatkan pemain-pemain utama iaitu kumpulan elit dalam wacana Turki-EU. İKV dijemput sama sebagai panel 
jemputan, peserta dan pemerhati dalam program libaturus di Eropah ataupun di Turki sendiri. Kerajaan Turki khususnya kementerian luar Turki turut mengiktiraf peranan IKKV berdasarkan pemerhatian penyelidik di pejabat Delegasi Tetap Turki di Brussels. Elmener (2017) merujuk hasil bancian dan penyelidikan IKKV sebagai sumber utama dalam perancangan dan pelaksanaan dasar luar Turki-EU. Sepanjang musim pandemik Covid-19, sejumlah siri webinar secara atas talian anjuran İKV telah menemukan panelis-panelis penting termasuklah dalam kalangan kementerian luar seperti Faruk Kaymakci (Timbalan Menteri Luar Turki), duta-duta besar dan pakar-pakar bidang Turki-EU yang lain.

Walaubagaimanapun, İKV kurang menumpukan aktiviti libaturus mensasarkan rakyat awam secara langsung (Servantie, 2017). Banyak sumber IKKV disalurkan dalam libaturus dengan kumpulan elit secara langsung dengan hasrat kumpulan elit memainkan peranan aktif mempengaruhi rakyat awam mereka terhadap matlamat strategik dasar luar Turki tersebut. Melalui pendekatan media baharu, capaian IKKV dilihat amat terbatas dan tidak membumi kepada rakyat Eropah secara langsung. Ini bermakna kumpulan elit dan pegawai kerajaan Turki menerima mesej tentang identiti, dasar dan nilai Turki secara langsung tetapi rakyat Eropah sendiri kurang menerima kefahaman yang jelas. Oleh yang demikian, pendekatan İKV terpaksa bergantung kepada kerjasama strategik dengan agensi-agensi diplomasi awam yang lain bagi memecahkan tembok kelemahan ini. Peranan ini digalas oleh pusat kebudayaan Yayasan Yunus Emre, dewan perniagaan seperti TÜSİAD dan MÜSİAD serta diaspora Turki (rakyat Turki yang menetap di Eropah) bagi memperbaiki komunikasi antara semua pihak berkepentingan (Servantie, 2017).

\section{Kedua: IKKV Mencairkan Anti-Turki}

Turki menerima tekanan yang kuat khususnya daripada kelompok haluan kanan dan aliran nasionalis di Eropah akibat persepsi negatif dan prejudis terhadap Turki yang mendominasi komuniti Eropah. Turki diasak dengan proses Islamisasi Eropah, jangkaan dominasi dalam Parlimen Eropah dan ancaman terhadap budaya dan sosial di Eropah. Minda komuniti Eropah secara umumnya mempercayai persepsi tersebut. Ini berpunca antara lain kerana sejarah lampau - kejatuhan Constantinople, persaingan kuasa zaman Uthmaniah dan Eropah serta pengalaman dalam Perang Dunia Pertama (Muftuler-Bac, 2007).

Cabaran dalam bentuk minda dan psikologi ini amat meresahkan Turki untuk memperbaiki salahtanggapan dan berusaha membina jambatan perdamaian dengan Eropah. Menteri Luar Turki, Cavusoglu menyatakan kerisauan fenomena ancaman perkauman sistemik terhadap komuniti Turki di Eropah Barat dan mendapat dokongan para pegawai di pelbagai peringkat (Siyaset, Ekonomi ve Toplum Araştırmaları Vakfı, 2020).

Impak utama untuk ditaksirkan adalah mencairkan anti-Turkisme dan memerangi Turkofobia dalam kalangan komuniti Eropah. Permainan persepsi adalah sesuatu yang 
yang amat berpengaruh khususnya pada zaman digital apabila sesuatu peristiwa atau insiden berlaku, ia mudah tular dan mempengaruhi emosi dan pemikiran masyarakat (Hatipoğlu, Muftuler-Bac \& Karakoc 2013). Sebagai contoh, isu Covid-19 pada tahun 2020 di Belgium mengundang persepsi yang negatif terhadap komuniti Turki yang menetap di Belgium apabila tular sebuah rakaman audio dalam aplikasi WhatsApp kononnya ramai pesakit yang dijangkiti virus Covid-19 adalah berbangsa Turki. Rentetan itu Menteri Alam Sekitar, Pelancongan dan Keadilan berbangsa Turki, Zuhal Demir mengumumkan dalam akaun Facebooknya mengecam dan menyeru secara terang supaya bangsa Turki mengikuti arahan kerajaan (Bayrakl1, 2020). Peristiwa seumpama ini merancakkan lagi kebencian dan prejudis terhadap rakyat Turki di Eropah. Kempen anti-Turki berlaku secara langsung dan secara tidak langsung melalui permainan persepsi akibat insiden yang sengaja atau tidak sengaja dalam kalangan komuniti Eropah (Hatipoğlu, Muftuler-Bac \& Karakoc, 2013).

Bagi tujuan mencapai impak ini, penyelidik mendapati İKV melancarkan pelbagai inisiatif untuk mencairkan anti-Turkisme seperti pertemuan libaturus, kempen media, penerbitan dan advokasi. Melalui penerbitan, İKV menerbitkan makalah dalam laman web yang bertajuk "Khurafat Lawan Fakta dalam Hubungan Turki-EU" yang menggariskan 20 salahfaham terhadap Turki (İktisadi Kalkınma Vakfı, 2016b). Selain itu, İKV aktif menganjurkan dan menyertai seminar dan webinar dalam pelbagai wacana yang membincangkan aspek budaya, politik, ekonomi dan sosial dalam hubungan antara Turki dan EU. Di peringkat tertinggi, mesyuarat dan pertemuan libaturus rasmi diadakan bagi menangani isu-isu berkaitan Turki-EU. Mesyuarat tersebut dihadiri Pesuruhjaya EU, pegawai agensi EU, pegawai kerajaan dan konsulat termasuklah sektor berkepentingan seperti dewan perniagaan, institusi penyelidikan dan agensi kerajaan yang berkenaan (Servantie, 2017).

Melalui insiatif - inisiatif yang dilaksanakan, İKV berpeluang berkongsi maklumat dan menjelaskan isu-isu secara lebih terperinci dan bersasar. Namun, penyelidik mendapati wujud banyak lagi kelompangan dan ruang advokasi yang masih belum diterokai IKKV. Sebagai perbandingan dengan SETA, sebuah badan pemikir Turki yang pro-kerajaan dilihat lebih agresif memanfaatkan sumbernya untuk menjalankan penyelidikan dan melaksanakan advokasinya di Eropah. Dengan tertubuhnya pejabat cawangannya yang baru di Brussels dan peranan koordinatornya Enes Bayraklı, wacana anti-Turkisme dan integrasi Turki-EU dilihat semakin rancak ditangani. İKV belum dapat menunjukkan hasil yang berkesan dalam memimpin pendapat umum di Eropah kerana pendekatan İKV lebih benyak mensasarkan kumpulan elit berbanding rakyat umum terbanyak. Ini kekurangan yang nyata dan terbukti akan merencatkan komunikasi Turki-EU dalam jangka masa panjang (Safwan, 2019).

\section{Ketiga: İKV Meraih Sokongan Komuniti Eropah}

Sokongan komuniti Eropah kepada hubungan Turki-EU adalah rendah berdasarkan bancian pendapat awam, Barometer dan respon komuniti dalam media sosial khususnya reaksi terhadap siri konflik Ankara-Brussels dalam isu-isu pelarian Syria, 
visa Turki ke Eropah, pembaharuan kerajaan dan pendemokrasian di Turki, Cyprus, kelembapan ekonomi, keganasan dan hak asasi manusia. Sjursen (2006) mendapati proses integrasi Turki-EU gagal dicapai tanpa perasaan kebersamaan (common feeling of togetherness) dan konsensus yang mengizinkan (permissive consensus). Sjursen juga menegaskan walaupun tiada penglibatan secara langsung antara pendapat umum dengan pelaksanaan dasar EU tetapi semua dasar EU hanya dilaksanakan dalam kerangka yang diterima oleh rakyat Eropah.

Dalam pentaksiran terhadap sokongan komuniti Eropah secara khususnya prokemasukan didasarkan kepada beberapa dimensi sistem kepercayaan (attitude) rakyat EU melihat dari sudut ekonomi, budaya dan politik. Sokongan juga bergantung kepada faktor taraf ekonomi, pendidikan dan kesedaran. Dalam Hatipoglu, Müftüler-Bac dan Karakoç (2013) mendapati semakin kanan ideologi politik maka semakin rendah sokongan kepada kemasukan Turki dalam EU. Semakin yakin Turki akan memberi manfaat kepada EU, semakin tinggi sokongan. Semakin banyak manfaat kepada Turki, semakin rendah sokongan rakyat EU. Elmener (2016) berpendapat rakyat Eropah umumnya menolak Turki atas faktor budaya dan identiti Turki kerana perbezaan agama Islam dan Kristian. Jurang yang wujud dalam beragama serta Islamofobia yang mendominasi wacana di Eropah masih lagi tebal dan melata dalam kalangan rakyat Eropah.

İKV menumpukan advokasi untuk meraih sokongan rakyat EU melalui kumpulan elit dan strategik seperti Suruhanjaya EU, agensi EU, ahli politik, dewan perniagaan dan sektor penyelidikan dan universiti (Servantie, 2018). Kumpulan ini menjadi sasaran utama İKV kerana mereka lebih berpengaruh dalam menentukan dasar dan keputusan penting. Inisiatif - inisiatif yang dilaksanakan İKV untuk meraih sokongan beberapa segmen utama di Eropah termasuklah menganjur dan menyertai seminar dan bengkel, usaha penyelidikan secara bersama dengan badan pemikir Eropah, mengadakan pertemuan libaturus dan aktiviti melobi serta membuka saluran komunikasi dengan agensi EU dan pihak-pihak berkepentingan dalam kerajaan termasuklah tokoh- tokoh politik EU.

Dalam pada itu, penyelidik mendapati IKV tidak menumpukan advokasi kepada media sedangkan institusi media berpengaruh dalam mencorakkan pemikiran dan persepsi rakyat awam. Penyelidik berpandangan agensi media tempatan di EU adalah kunci penting kepada saluran komunikasi rakyat umum dan medium yang efektif. Media sosial juga tidak dapat dinafikan sebagai sumber maklumat utama masa kini yang diakses oleh setiap lapisan rakyat umum.

Impak yang positif terhadap Turki boleh dijana dengan merumuskan kerjasama dalam semua sektor termasuklah kesenian, kebudayaan, khidmat masyarakat, kemanusiaan, perniagaan dan teknologi. Semua sektor dan lapisan masyarakat yang saling berkerjasama akan menyerlahkan hakikat keamanan dan kepentingan bersama. Inilah kebersamaan yang diburu oleh kedua-dua pihak secara organik dan sukarela. 


\section{Keempat: IKV Mendorong Komuniti Eropah Berkongsi Tentang Turki}

Pencapaian yang dihasratkan oleh Turki ialah apabila rakyat Eropah menerima dan menyukai Turki untuk tujuan kemasukan ke dalam EU. Kejayaan menukar kepercayaan daripada prejudis kepada nilai hormat dan menghargai boleh diukur dengan tindakan daripada rakyat EU berkongsi nilai, cerita, kejayaan, kelebihan dan pencapaian Turki. Perkongsian tersebut boleh berlaku disebBBKan mana-mana lapisan struktur seperti individu, komuniti, badan-badan bukan kerajaan, pemimpin dan kerajaan.

Sebagai contoh, kerajaan Turki menanggung 4 juta pelarian Syria sebagai satu simbol kemanusiaan yang tinggi (Bayer \& Keyman, 2012). Dasar dan sikap bukan sahaja kerajaan Turki tetapi rakyat dan badan bukan kerajaan dalam menangani isu kemanusiaan terbesar ini membentuk satu persepsi dan hormat dalam pemikiran rakyat EU. Kefahaman terhadap identiti dan akhlak mula menjadi terbina dan rancak diperbincangkan dalam kalangan rakyat EU.

IKKV dalam hal ini berperanan berkongsi dan mengarusperdanakan nilai dan cerita yang berpotensi meningkatkan sokongan dan minat terhadap Turki. Ketika menghadapi kebuntuan dalam hubungan Turki-EU, IKKV meneruskan aktiviti libaturus melalui siri webinar untuk berkongsi, menyalurkan idea dan meningkatkan persefahaman sesama peserta dalam tema-tema utama hubungan Turki-EU (Servantie, 2017). Secara tidak langsung, IKKV membentangkan nilai bersama (shared values) dan sikap bekerjasama sebagai asas penting kepada proses integrasi Turki-EU. Selain itu, IKKV juga berusaha menonjolkan kemampuan dan kelebihan Turki dalam pelbagai sektor khususnya dalam industri pembuatan, teknologi, pertanian, kebudayaan, perfileman dan kemanusiaan. Melalui advokasi tersebut, Turki dilihat sebagai bernilai dan pemain yang penting dalam EU.

Impak yang digariskan di atas antara matlamat-matlamat utama yang berupaya memacu projek integrasi Turki-EU setelah lebih enam abad. Tidak dapat dinafikan aspek pembaharuan politik, perundangan dan ekonomi juga syarat-syarat yang penting seperti termaktub dalam Kriteria Copenhagen dan Acquis Communitaire. Bagi sebuah badan pemikir dan juga agen diplomasi awam seperti IKKV, strategi komunikasi dan peranan yang dimainkan kekal relevan dan berpotensi menjana perubahan yang signifikan dalam hubungan Turki-EU.

\section{Saranan}

Hubungan Turki-Eropah telah melalui sejarah perjalanan yang panjang dan untuk tempoh 10 tahun mendatang dijangkakan Turki akan berdepan krisis, polemik dan situasi lebih sulit, berdasarkan faktor-faktor geopolitik, ekonomi dan sosio-budaya. Beberapa saranan dasar (policy recommendations) telah digariskan jika İKV ingin mengukuhkan strategi advokasi dan diplomasi, ketika hubungan Ankara-Brussels masih dalam kesamaran (uncertainty) dan dilihat cenderung kepada "retak menanti belah" (fragile). Perubahan yang berlaku mendorong tindakan yang lebih konkrit dan 
bersasar kepada kelompok yang berpengaruh dan komuniti Eropah keseluruhannya. Saranan-saranan yang digariskan dibentuk atas konsep 3P iaitu Pemain (Player), Program dan Perkongsian Kuasa (Power Sharing).

\section{Meluaskan libaturus kepada pemain-pemain baru di Eropah.}

Walaupun dikenali sebagai BBK berpengalaman dalam arena hubungan Turki-EU, IKV masih belum berjaya menembusi beberapa segmen masyarakat yang penting termasuklah komuniti diaspora Turki yang menetap di Eropah, agensi-agensi media tempatan dan pertubuhan-pertubuhan berkepentingan. Ini menjawab persoalan mengapa ramai warga Turki sendiri di Eropah masih keliru atau kurang maklumat dengan strategi-strategi integrasi yang dijuarai oleh Turki. Agensi-agensi media di Eropah yang pro-Euroskeptik dan anti-imigran misalnya menjadikan krisis AnkaraBrussels sebagai modal berita serta mendapat habuan khususnya oleh elit politik yang berpengaruh. Komuniti Eropah amat terdedah dengan pemberitaan sensasi yang dimainkan media massa serta kemunculan generasi media digital yang membuka ruang seluasnya kepada jurnalisme rakyat. Kandungan media yang sarat dengan kebencian, berita palsu dan berat sebelah akan menyulitkan proses pendidikan komuniti secara sihat dan bernilai.

\section{Memperkukuhkan hubungan dengan aparatus EU.}

IKKV perlu mendapatkan kepercayaan EU dengan mengekalkan hubungan baik dengan agensi-agensi dan institusi-institusi EU serta mempengaruhi dasar-dasar integrasi yang menguntungkan semua pihak. Hubungan yang telah dibina sejak penubuhan İKV sehingga era kini didapati membuahkan kemajuan tetapi krisis politik, ekonomi serta sosial yang berlarutan telah menjejaskan hubungan Ankara-Brussels. Perkara ini sangat kritikal. Walaupun İKV hanya sebuah BBK dengan sumber-sumber yang terhad, peranan IKV dalam advokasi melalui libaturus dalam platform dan jawatankuasa anjuran EU dapat mengukuhkan kesefahaman serta meluruskan kekeliruan dalam kalangan birokrat EU.

\section{Memperbaiki komunikasi dengan semua pihak.}

Komunikasi amat penting dan kritikal. Dalam konteks keberkesanan peranan pemainpemain dalam wacana Ankara-Brussels, IKKV diperlukan sebagai jambatan antara kerajaan Turki dan EU melalui peranan memudahcara (facilitator) serta menampung kelemahan aparatus kerajaan Turki secara berterusan mengemukakan pendapat dan kepakaran khususnya dalam aspek pembangunan strategi, dasar dan proses keanggotaan.

\section{Menyemarakkan advokasi melalui kempen kesedaran.}

Berdasarkan dapatan bancian yang dijalankan İKV, tahap kesedaran dan maklumat dalam kalangan rakyat Turki masih rendah di samping kekeliruan fakta yang berlegar di ruang maya dan awam. Inisiatif advokasi melalui kempen kesedaran secara bersasar perlu disemarakkan bagi memperbaiki pandemik maklumat yang sedang merencatkan proses integrasi yang masih diperjuangkan kerajaan Turki, majoriti rakyat dan 
kelompok masyarakat. İKV juga perlu menilai semula keberkesanan kempen-kempen yang telah dijalankan sebelum ini dengan menjana lebih banyak platform atau saluran yang mesra pengguna seperti penggunaan media sosial, webinar atas talian, promosi dan iklan yang berimpak tinggi.

\section{Menjana sumber diplomasi awam baru melalui kempen bersasar, produk pelancongan dan nilai sejagat.}

Maqasid utama diplomasi awam adalah memastikan mesej sampai kepada kumpulan sasaran asing. Dalam konteks ini, İKV perlu menggerakkan aparatus sendiri dan bersinergi dengan pihak-pihak lain untuk mempromosikan nilai-nilai, produk pelancongan dan kemajuan dalam sektor utama Turki kepada warga EU. Ini dapat melonjakkan imej positif serta melenyapkan persepsi negatif yang menghujani Turki sejak sekian lama.

\section{Membentuk platform baru yang menaikkan imej dan melicinkan komunikasi.}

Berdasarkan takwim İKV, beberapa siri jelajah di bandar-bandar utama Eropah telah dilaksanakan İKV untuk mengupas wacana Ankara-Brussels khususnya dalam kalangan kelompok akademia, pemikir dan aktivis masyarakat madani. Secara makro, proses advokasi tersebut masih jauh daripada sasaran dan akses kepada mesej yang dibincangkan amat terhad. Pada hemat penyelidik, walaupun Turki tidak menyertai EU, platform - platform advokasi yang memperkenalkan keunikan negara, memperbaiki salahtanggapan serta menaikkan imej negara wajar terus disemarakkan.

\section{Memperkasakan aktiviti lobi.}

Dalam situasi tegang dan dingin antara Ankara-Brussels yang berlarutan, ruang komunikasi sewajarnya terus dibuka. Aktiviti melobi pihak-pihak berkepentingan seperti pembuat dasar, ahli parlimen, pegawai tertinggi EU serta agensi utama perlu diperkasakan. Pendekatan bersemuka atau atas talian, mengutus surat rasmi, mengemukakan saranan secara berkala berpotensi membantu kumpulan sasaran tersebut mengemaskini maklumat mereka dan memahami keperluan atau permohonan yang disampaikan.

\section{Merangsang pemimpin Turki dan EU untuk saling memahami melalui platform} kerjasama.

Tidak dapat dinafikan, faktor penentu paling utama yang mengizinkan penyertaan Ankara dalam EU merupakan sokongan oleh kelompok pemimpin EU. Dalam situasi krisis yang masih membelenggu masa depan Ankara dalam EU, Turki ada pilihan untuk merangsang persefahaman melalui elit pemimpin, aparatus kementerian luar dan agensi-agensi berkepentingan seperti İKV sendiri. Platform komunikasi harus dibuka seluasnya dan memacu kerjasama dalam pelbagai sektor.

\section{Menjana polisi yang lebih berkesan}

Ini bagi melicinkan usaha memenuhi syarat keanggotaan dalam EU. Kerajaan Turki telah menggariskan beberapa strategi komunikasi dan garispanduan kepada semua 
kementerian dan sektor agar memenuhi standard dan kehendak Acquis. Namun, polisipolisi yang dijana kurang berkesan dan berhalangan untuk dilaksanakan. Antara halangan utama adalah kesedaran yang rendah dalam kalangan penjawat awam, ketua BBK, sektor bisnes dan pihak berkepentingan dalam memenuhi garispanduan Acquis oleh EU, sikap dan tindakan yang bertentangan dengan proses integrasi dalam kalangan sebahagian rakyat termasuklah kejadian dan insiden yang secara langsung merencatkan hubungan Turk-EU.

Saranan-saranan yang digariskan di atas merupakan hasil pemerhatian yang mendalam terhadap perkembangan hubungan Turki-EU dalam tempoh antara 2014 dan 2021. Perubahan yang dijana oleh pihak berkepentingan dan strategik akan membuka jalan yang lebih positif dalam situasi yang tegang dan hangat antara Turki dan EU sekian lama. Masa juga bakal menentukan kesudahan hubungan Turki-EU setelah sekian lama "bertunang" tanpa "ikatan pernikahan" yang diharap-harapkan oleh Turki.

\section{Kesimpulan}

Negara-negara peneraju dalam bidang pembangunan penyelidikan dan pasaran dasar seperti Amerika Syarikat dan negara-negara Eropah telah berjaya menjadikan sektor badan pemikir sebagai aktor yang mampu mempengaruhi keputusan dalam dasar-dasar penting, samada skala domestik negara atau hubungan antarabangsa. Badan pemikir berperanan menjadi pendesak, enjin kuasa dan pemangkin utama dalam pelbagai sektor strategik seperti politik, ekonomi, tadbirurus, keselamatan, hubungan luar, pembangunan sosial dan perundangan. Perkembangan dan pertumbuhan sektor BBK ini dilihat merangsang perubahan yang bersifat lebih holistik, menyelesaikan dan lestari dalam jangka masa yang panjang.

Dalam konteks hubungan Ankara-Brussels, badan pemikir menghasilkan impak kepada matlamat-matlamat dasar luar yang digariskan. Secara khusus, ia berperanan untuk menganalisa isu-isu kritikal, membentuk saranan-saranan penyelesaian dan memformulasikan dasar-dasar yang strategik khusus dalam wacana hubungan TurkiEU. Matlamat strategik kerajaan Turki menganggotai EU telah menjadi visi bersama (shared vision) oleh İKV, sebuah badan pemikir yang berpengalaman dan berpengaruh khususnya dalam kalangan komuniti industri, usahawan dan akademia.

Semenjak 1965, İKV telah memainkan peranan yang penting melalui usaha-usaha penyelidikan, inisiatif diplomatik dan aktiviti melobi dalam rangka mengeratkan hubungan Ankara-Brussels. İKV bertindak sebagai "enjin utama" yang mewakili sektor bukan kerajaan yang independen dalam proses integrasi Ankara-Brussels serta menjadi agen diplomasi awam yang boleh diharapkan menjayakan matlamat strategik dasar luar Turki. Kekuatan yang dimiliki IKKV adalah modal insan yang terdiri daripada susuk individu yang professional, kompeten dan berpengaruh dalam mengatur libaturus dan dialog dengan pihak EU. İKV juga mengamalkan sikap independen dan bipartisan untuk menjamin kredibiliti dalam menyumbangkan nilai tambah kepada wacana Ankara-Brussels. Dalam arena diplomasi, kriteria ini amat diperlukan dan membantu 
proses pembangunan diplomasi awam. Secara keseluruhan, usaha dialog dan rundingan damai memacu proses merungkai konflik dan pertembungan ketamadunan silam yang sekian lama telah membelenggu negara-negara Eropah termasuk Turki.

\section{Rujukan}

Aksit, S, Senyuva, O. \& Ustun, C. (pnyt.). (2009). Turkey Watch EU Members' States Perceptions on Turkey's Accession to the EU. Ankara: Centre for European Studies.

Anon. (2009). Think-Tanks Should Join EU Lobby Register, Kallas Insists. Diambil daripada https://www.euractiv.com/section/public\%20-affairs/news/thinktanks-should-join-eu-lobby-register-kallas-insists/.

Asia-Europe. (t.th). Academic Senior Advisors. Diambil daripada https://aei.um.edu.my/academics-amp-senior-advisors\#.

Astakhova, O. \& Sezer, C. (2020). Turkey, Russia Launch TurkStream Pipeline Carrying Gas to Europe. Reuters.

Bardakci, M. (2017). Funeral in Bebek Mosque. Diambil daripada https://www.haberturk.com/yazarlar/murat-bardakci/1743060-bebekcamiindeki-cenaze.

Baser, M. (2017). Turkey's Accession into EU. Temu bual, 27 Julai.

Bayer, R. \& Keyman, E. F. (2012). Turkey: An Emerging Hub of Globalization and Internationalist Humanitarian Actor? Globalization, 9(1).

Bayrakl1, E. (2020). 5 Questions: COVID-19 Pandemic and Racist Accusations against the Turkish Community in Belgium. Diambil daripada https://www.setav.org/en/5-questions-covid-19-pandemic-and-racistaccusations-against-the-turkish-community-in-belgium/.

Cull, N. (2008). Public Diplomacy: Taxonomies and Histories. The Annals of the American Academy of Political and Social Science, 616(1): 31-54

Donelli, F. (2020). Explaining the Role of Intervening Variables in Turkey's Foreign Policy Behaviour. Interdisciplinary Political Studies 6(2): 230.

Elmener, B. (2017). Keanggotaan Turki dalam EU, Brussels. Temu bual, 25 Januari. European Economic and Social Committee. (2019). 38th Meeting of the EU-Turkey Joint Consultative Committee. Diambil daripada https://www.eesc.europa.eu/en/agenda/our-events/events/38th-meeting-euturkey-joint-consultative-committee.

Elmener, B. (2017). Turkey's Accession into EU. Temu bual. 25 Januari.

Gilroy, P. (2012). Have Think Tanks in Washington D.C. Become Politicized? Hertie School of Governance. Diambil daripada https://hal.archives-ouvertes.fr/hal00817797/document.

Hatipoğlu, E., Müftüler-Bac, M., \& Karakoç, E. (2013). Explaining Variation in Public Support to Turkey's EU Accession, Turco-skepticism in Europe: A Multi-Level Analysis. MAXCAP: Berlin. Diambil daripada http://userpage.fuberlin.de/kfgeu/maxcap/system/files/maxcap_wp_04_0.pdf. 
İktisadi Kalkınma Vakfi. (2016a). İKV: Turkish Private Sector's Specialised Institution On EU. Diambil daripada https://www.IKV.org.tr/IKV.asp?ust id=2\&id=10.

İktisadi Kalkınma Vakfı. (2016b). Myths vs Facts on Turkey-EU Relations. Diambil daripada https://dby.IKKV.org.tr/en/.

Kalın, I. (2011). Soft Power and Public Diplomacy in Turkey. Perceptions. Journal of International Affairs.

Kantouris, C., Bilginsoy, Z. \& Gatopoulos, D. (2020). Greece, Turkey Signal

Willingness To Talk About Sea Dispute. Diambil daripada

https://apnews.com/article/turkey-archive-greece-

9d9cc12fc83c7c60d4116f3415bc14b6.

Keohane, R.O \& Nye J.S. (1972). Transnational Relations and World Politics. Cambridge: Harvard University Press.

Lecha, E. S. (2019). EU-Turkey relations: Mapping landmines and exploring alternative pathways. Foundation for European Progressive Studies. FEPS Policy Paper. September 2019.

Lee, G. \& Ayhan, K. (2015). Why Do We Need Non-State Actors in Public Diplomacy?: Theoretical Doscussion of Relational, Networked and Collaborative Public Diplomacy. Journal of International and Area Studies, 22(1): 60 .

Matwiczak, K, (2010). Public Diplomacy Model for the Assessment of Performance.

The University of Texas at Austin. Diambil daripada

https://www.peacepalacelibrary.nl/ebooks/files/372557988.pdf . Diambil pada: 3 Mac 2016.

McGann, J. (2012). Global Trends in Think Tanks and Policy Advice. Pennsylvania: University of Pennsylvania Press.

McGann, J. (2020). 2019 Global Go To Think Tank Index. Philadelphia: University of Pennsylvania.

Mellisen, J. 2005. The New Public Diplomacy: Between Theory and Practice. Dlm. Mellisen, Jan (pnyt.). The New Public Diplomacy: Soft Power in International Relations. Basingstoke: Palgrave Macmillan.

Montada, A. \& Mendizabal E. (2013). Think Tank Boards: Composition and Practices. Diambil daripada https://onthinktanks.org/articles/think-tank-boardscomposition-and-practices/.

Muftuler-Bac, M. (2007). Turkey's Accession to the European Union: Does Culture and Identity Play a Role? Ankara Review of European Studies, 6(2), Spring.

Nas, C. (2021). June European Council and Positive Agenda in Turkey-EU Relations: Is There Light at the End of Tunnel? Brief, 65, July. Economic Development Foundation.

Nichelson, S. (2009). EU Think Tanks in Brussels: Policy-Making Roles, Functions and Influence. Katholieke Universiteit Leuven: Brussels.

Noel, E. (1988). E. Noel conference sur la Turquie 3/1988 cite pat C. Previti dans la presentation des archives d'Emile Noel, archives europeennes de Florence.

Nye, J. S. (2011). The Future of Power. New York: Public Affairs. 
Oguz, M. (2008). ASAM: Closure Making Think Tanks Think Harder. Diambil daripada http://www.hurriyet.com.tr/asam-closure-making-think-tanks-thinkharder-10417056. Reuters. (2020). EU says Hagia Sophia mosque decision 'regrettable'. Diambil daripada https://www.reuters.com/article/us-turkeymuseum-eu/eu-says-hagia-sophia-mosque-decision-regrettableidUSKBN24B2SN.

Safwan Saparudin \& Russli Kamaruddin. (2019). Politik Islamofobia Dalam Wacana Keanggotaan Turki ke dalam Kesatuan Eropah: Sebuah Sorotan. Jurnal Peradaban, 12(1).

Siyaset, Ekonomi ve Toplum Araştırmaları Vakfı (SETAV). (2020). Turks in Europe Face Systemic Racism: Turkish FM. Diambil daripada https://www.setav.org/en/turks-in-europe-face-systemic-racism-turkish-fm/.

Servantie, D. (2018). The Role of the Economic Development Foundation in TurkeyEU Accession Process. Laporan Ilmiah. Universite Saint-Louis: Brussels.

Servantie, D. (2017). Peranan IKV dalam proses Keanggotaan Turki dalam EU. Temu bual. 27 September.

Sherrington, P. (2000). Shaping the Policy Agenda: Think Tank Activity in the European Union. Global Society, 14: 173-189

Stone, D. (2000). Introduction to the Symposium: The Changing Think Tank Landscape. Global Society, 14(2):149-152

Sjursen, H. (2006). Questioning EU Enlargement: Europe in search of identity. New York: Routledge.

TOBB. (t.th). Turkey - EU Joint Consultative Committee. Diambil daripada https://www.tobb.org.tr/AvrupaBirligiDairesi/Sayfalar/Eng/CSforEUJCC.php.

Tocci, N. (2016). Turkey and the European Union: Scenarios for 2023. FEUTURE Background Paper. Istituto Affari Internazionali.

Tocci, N. (2014). Turkey and the European Union: A Journey in the Unknown.

Turkey Project Policy Paper. The Center on the United States and Europe (CUSE) at Brookings. No. 4 (November).

Willis, A. (2009). Commission Criticises Think-tanks Over Lobby Register. Diambil daripada https://euobserver.com/political/27959.

World Migration Report. (2020). Diambil daripada https://publications.iom.int/system/files/pdf/wmr_2020.pdf. 